NASA/TM-2002-211915

\title{
Solid Hydrogen Experiments for Atomic Propellants: Particle Formation Energy and Imaging Analyses
}

Bryan Palaszewski

Glenn Research Center, Cleveland, Ohio 
Since its founding, NASA has been dedicated to the advancement of aeronautics and space science. The NASA Scientific and Technical Information (STI) Program Office plays a key part in helping NASA maintain this important role.

The NASA STI Program Office is operated by Langley Research Center, the Lead Center for NASA's scientific and technical information. The NASA STI Program Office provides access to the NASA STI Database, the largest collection of aeronautical and space science STI in the world. The Program Office is also NASA's institutional mechanism for disseminating the results of its research and development activities. These results are published by NASA in the NASA STI Report Series, which includes the following report types:

- $\quad$ TECHNICAL PUBLICATION. Reports of completed research or a major significant phase of research that present the results of NASA programs and include extensive data or theoretical analysis. Includes compilations of significant scientific and technical data and information deemed to be of continuing reference value. NASA's counterpart of peerreviewed formal professional papers but has less stringent limitations on manuscript length and extent of graphic presentations.

- TECHNICAL MEMORANDUM. Scientific and technical findings that are preliminary or of specialized interest, e.g., quick release reports, working papers, and bibliographies that contain minimal annotation. Does not contain extensive analysis.

- CONTRACTOR REPORT. Scientific and technical findings by NASA-sponsored contractors and grantees.
- CONFERENCE PUBLICATION. Collected papers from scientific and technical conferences, symposia, seminars, or other meetings sponsored or cosponsored by NASA.

- SPECIAL PUBLICATION. Scientific, technical, or historical information from NASA programs, projects, and missions, often concerned with subjects having substantial public interest.

- TECHNICAL TRANSLATION. Englishlanguage translations of foreign scientific and technical material pertinent to NASA's mission.

Specialized services that complement the STI Program Office's diverse offerings include creating custom thesauri, building customized databases, organizing and publishing research results ... even providing videos.

For more information about the NASA STI Program Office, see the following:

- Access the NASA STI Program Home Page at http://www.sti.nasa.gov

- E-mail your question via the Internet to help@sti.nasa.gov

- Fax your question to the NASA Access Help Desk at 301-621-0134

- Telephone the NASA Access Help Desk at 301-621-0390

- Write to:

NASA Access Help Desk

NASA Center for AeroSpace Information 7121 Standard Drive

Hanover, MD 21076 
NASA/TM-2002-211915

AIAA-2002-4092

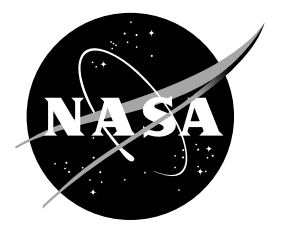

\section{Solid Hydrogen Experiments for Atomic Propellants: Particle Formation Energy and Imaging Analyses}

Bryan Palaszewski

Glenn Research Center, Cleveland, Ohio

Prepared for the 38th Joint Propulsion Conference and Exhibit cosponsored by the AIAA, ASME, SAE, and ASEE Indianapolis, Indiana, July 7-10, 2002

National Aeronautics and

Space Administration

Glenn Research Center 


\section{Acknowledgments}

I'd like to thank the people who assisted in the construction and execution of the experiments conducted at NASA Glenn Research Center: Maureen Kudlac (GL), Henry Speier, Joan Hoopes, Ernie Bell, Donald Metcalf, and Robert Vanek. Thanks to Hugh Aylward for the image capturing and pixel measurements of the particle sizes. I'd also like to thank John Cole, head of Space Transportation Research (STR) aspects of the NASA Advanced Space

Transportation Program (ASTP), led by NASA Marshall Space Flight Center. Extensive cooperation with the USAF Research Laboratory (Edwards, California) was also a critical part of this testing.

Available from

NASA Center for Aerospace Information 7121 Standard Drive

Hanover, MD 21076
National Technical Information Service 5285 Port Royal Road Springfield, VA 22100 


\title{
SOLID HYDROGEN EXPERIMENTS FOR ATOMIC PROPELLANTS: PARTICLE FORMATION ENERGY AND IMAGING ANALYSES
}

\author{
Bryan Palaszewski ${ }^{*}$ \\ National Aeronautics and Space Administration \\ Glenn Research Center \\ Cleveland, Ohio 44135 \\ Phone: 216-977-7493, Fax: 216-433-5802 \\ Email: bryan.a.palaszewski@grc.nasa.gov
}

\begin{abstract}
$\underline{\text { ABSTRACT }}$
This paper presents particle formation energy balances and detailed analyses of the images from experiments that were conducted on the formation of solid hydrogen particles in liquid helium during the Phase II testing in 2001. Solid particles of hydrogen were frozen in liquid helium, and observed with a video camera. The solid hydrogen particle sizes and the total mass of hydrogen particles were estimated. The particle formation efficiency is also estimated. Particle sizes from the Phase I testing in 1999 and the Phase II testing in 2001 were similar. Though the 2001 testing created similar particles sizes, many new particle formation phenomena were observed. These experiment image analyses are one of the first steps toward visually characterizing these particles, and allow designers to understand what issues must be addressed in atomic propellant feed system designs for future aerospace vehicles.
\end{abstract}

\section{NOMENCLATURE}

$\begin{array}{ll}\text { ASTP } & \text { Advanced Space Transportation Program } \\ \text { DOE } & \text { Department of Energy } \\ \text { FCC } & \text { Face centered cubic } \\ \text { FOV } & \text { Field of view } \\ \text { GLOW } & \text { Gross lift off weight } \\ \text { GRC } & \text { Glenn Research Center (formerly known as } \\ & \text { Lewis Research Center (LeRC)) } \\ \mathrm{H} & \text { Atomic hydrogen } \\ \mathrm{HCP} & \text { Hexagonal close pack } \\ \mathrm{H}_{2} & \text { Molecular Hydrogen } \\ \mathrm{He} & \text { Helium } \\ \text { LLNL } & \text { Lawrence Livermore National Laboratory }\end{array}$

AIAA Associate Fellow, Leader, NASA Advanced Fuels,

Fuels and Space Propellants Web Site

http://sbir.grc.nasa.gov/launch/foctopsb.htm
NASA National Aeronautics and Space

Administration

NLS National Launch System

$\mathrm{O} / \mathrm{F} \quad$ Oxidizer to fuel ratio

SMIRF Small Multipurpose Research Facility

STR Space Transportation Research

USAF United States Air Force

wt $\%$ Weight percent

$\mathrm{x} / \mathrm{L} \quad$ Non-dimensional distance from dewar lid

\section{INTRODUCTION}

For over 69 years, the promise of atomic propellants has been pursued (Refs. 1 to 33). Using atoms of boron, carbon, or hydrogen, maintained at cryogenic temperatures, very exciting advances in rocket propellants and airbreathing fuels can be created. Atomic propellants are composed of atomic species stored in cryogenic solid hydrogen particles. These particles are stored in liquid helium to prevent the recombination of the atoms into molecules. Once the hydrogen is warmed, and the atoms allowed to recombine, the recombination energy heats the hydrogen and helium to high temperatures, and the resulting gases can be directed in a traditional converging-diverging nozzle to create thrust and, theoretically, high specific impulse (Refs. 3 to 7).

Over the decades, many details of the physics of storing such propellants have been analyzed and experimentally determined. Current research is underway with a team from the USAF, NASA, the DOE, university, industry, and small business partners (Ref. 2). The extensive data that has been amassed over many decades have shown increasing storage densities for atoms in solid cryogenic storage media, and that 
there may be future breakthroughs that allow the more routine use of atoms for fuels.

Characterizing solid hydrogen particles is required before any practical propellant feed system can be created. Solid hydrogen particles were selected as a means of storing atomic propellants in future launch vehicles. When storing atoms of boron, carbon, hydrogen, or other atomic materials, a solid hydrogen particle is preferred. Very low temperature $(\mathrm{T}<4 \mathrm{~K})$ cryogenic particles have the ability to stabilize and prevent the atoms from recombining and controlling their lifetime. The particles and the atoms must remain at this low temperature until the fuel is introduced into the engine combustion (or recombination) chamber.

\section{WHY ATOMIC PROPELLANTS?}

In the future, rocket and airbreathing propulsion systems may be able to gain great benefits from the enormous power of atomic propellants. A summary of atomic hydrogen rocket gross lift off weight (GLOW) is shown in Figure 1 (Ref. 3). Using a 15-wt\% atomic hydrogen fuel, the gross lift off weight of the launch vehicle can be reduced by $50 \%$ over the National Launch System (NLS) using $\mathrm{O}_{2} / \mathrm{H}_{2}$ propellants. The baseline rocket and payload weight for the comparison is an oxygen /hydrogen rocket taking 96,000 kg of payload to Earth orbit. For the atomic hydrogen fuel, the oxidizer to fuel $(\mathrm{O} / \mathrm{F})$ ratio is 0.0 , using the fuel as a monopropellant Additional analyses and suggested optimal fuel selections for atomic rocket vehicles are presented in Refs. 3 to 7.

\section{SOLID HYDROGEN EXPERIMENTS}

Solid hydrogen particle formation in liquid helium was experimentally investigated. Experiments were planned to do visual characterizations of the particles, estimate their masses, and estimate the production efficiency. The particle sizes were estimated from video image analyses, similar to those presented in Refs. 9 and 10. The work presented here is the detailed studies of the Phase II (2001) video images, which precisely measured the particles sizes. This set of Phase II (2001) test analyses includes the analyses of numerous images, and numerous particles in each image. A mass estimate of the solid hydrogen particles was conducted. Using the particle size analyses and dewar gas outflow data, a solid hydrogen production efficiency was estimated.

\section{EXPERIMENTAL SETUP}

The experiments were conducted in the Small Multipurpose Research Facility (SMIRF, formerly the Small Multilayer Insulation Research Facility, Ref. 12).
The facility has a vacuum tank, into which the experimental setup was placed. The vacuum tank was used to prevent heat leaks and subsequent boiloff of the liquid helium, and the supporting systems maintain the temperature and pressure of the liquid helium bath where the solid hydrogen particles were created.

The experimental setup included several key components. Figure 2 depicts the helium dewar and the associated liquid hydrogen tank. A small cryogenic dewar was used to contain the helium bath, in which the solid hydrogen particles were formed. The dewar was $711.2 \mathrm{~mm}$ (28 inches) in height, with a $609.6 \mathrm{~mm}$ (24 inch) inside depth and had an inside diameter of $315.9 \mathrm{~mm}$ (12.438 inches). To create the solid hydrogen, liquid hydrogen at a temperature of 14 to $18 \mathrm{~K}$ was used. To contain the liquid hydrogen, a small stainless steel tank was used, which was $152.4 \mathrm{~mm}$ (6 inches) in diameter, and $609.6 \mathrm{~mm}$ (24 inches) long. As shown in Figure 2, the tank was mounted above the dewar. To control the hydrogen flow, a precision flow valve was used, and a video camera recorded the particle formation. All of the flow control for the liquid hydrogen, liquid and gaseous helium, and nitrogen purge gases was provided by the SMIRF systems.

The field of view (FOV) of the camera versus the distance from the dewar lid was computed. Figure 3 compares the camera field of view with the dewar diameter. Once the liquid helium's free surface is at $\mathrm{x} / \mathrm{L}=0.43(315.9 \mathrm{~mm}$, or 12.0 inches, with $\mathrm{L}=711.2$ $\mathrm{mm}$ (28 inches)), the liquid's entire surface is in the FOV. For runs, the helium liquid level was maintained at nearly 355.6 to $406.4 \mathrm{~mm}$ (14 to 16 inches) from the dewar lid. This location was chosen based on the knowledge of the field of view of the camera, and the need to observe as much of the liquid surface as possible.

Table I shows the locations of the silicon diodes for the temperature measurements. As these temperature measurements were used to establish the location of the helium surface and overall image sizes and field of view, the diode locations are presented. The Phase II temperature profiles in the helium dewar are presented in Figure 4. The diodes have a temperature accuracy of \pm 1 degree $\mathrm{K}$, and they are attached to a non-metallic rake, composed of circuit board material that extended from the dewar lid into the liquid helium. The diodes were mounted on the rake. Circuit board material was used as it had a low thermal conductivity, it was readily available, and was easily cut to the proper dimensions. A polycarbonate screw attached the top end of the circuit board to a polycarbonate rod. The upper end of the polycarbonate rod was threaded and screwed into the underside of the helium dewar lid. 
Table I.-Silicon diode locations in helium dewar L, dewar $=711.2 \mathrm{~mm}$ (28 inches)

\begin{tabular}{lc}
\hline Name & $\begin{array}{c}\text { Location below dewar } \\
\text { lid (inches) }\end{array}$ \\
\hline SD4 & 0 \\
LL1 & 2 \\
LL2 & 4 \\
LL3 & 7 \\
LL4 & 10 \\
LL5 & 12 \\
LL6 & 14 \\
LL7 & 16 \\
LL8 & 19 \\
LL9 & 22 \\
\hline
\end{tabular}

\section{EXPERIMENTAL PROCEDURE}

During the experimental runs, a small amount of liquid hydrogen was dropped onto the surface of the liquid helium. The hydrogen flow rate selected was $1 / 500$ th liter per second. This flow rate was selected by comparing the total heat capacity of the hydrogen versus the helium. Selecting a high flow rate would create a very high helium vaporization rate, and loss of the liquid helium. With the low flow rate, the particles formation is clearly observed, and it eliminates any chance of the relatively warm liquid hydrogen vaporizing all of the liquid helium in the dewar. Only a small amount of the liquid helium contained in a dewar vaporized as it froze the hydrogen particles.

In the first step of the hydrogen freezing process, the liquid hydrogen temperature was subcooled to 14 to $18 \mathrm{~K}$. This process allowed the hydrogen to be at a very low temperature, near its freezing point. Comparisons of the heat capacity of helium and the heats of liquefaction and fusion (solidification) of hydrogen led to the selection of conditioning the hydrogen to a very low temperature before releasing it onto the helium surface. Otherwise a large amount of helium would have been used to condense the gaseous hydrogen, liquefy it, and then finally freeze the hydrogen into solid particles. Large clouds of vapor that are created during higher speed hydrogen freezing would have also obscured the formation process, and thwarted efforts to see the final particles. After the hydrogen particles freeze, they are observed for many minutes.

Many frames from the videotape of the experiment were captured and analyzed. Table II summarizes the timing for the experimental runs, where each solid hydrogen formation run began. There was an interval of between 25 and 65 minutes between runs. These time spans were chosen to allow the particles to agglomerate, and to observe any unusual activity of the solid hydrogen.

\section{EXPERIMENTAL APPARATUS IMPROVEMENTS FOR 2001 TESTING}

The 2001 Phase II testing included a number of improvements to the experimental apparatus used in Phase I (1999). The lighting in the dewar was improved with a high intensity light, and a silvered cone to reflect light into spaces that were shadowed in the Phase I testing. The mass flow into and out of the dewar is shown notionally in Figure 6. The gas composition of the venting gases from the dewar was measured with increased accuracy with the addition of a Residual Gas Analyzer (RGA). A heat exchanger was fabricated and added to the gas space above the liquid helium. The heat exchanger was to help reduce the temperature of the gas above the liquid surface. The insulation and cooling of the precision hydrogen valve was improved. A more reliable operation of the valve was needed to assure the proper small amount of hydrogen was introduced into the dewar.

Many more runs were conducted in the 2001 Phase II testing. The experience in the 1999 Phase I testing allowed for a much greater frequency of testing, and the new operational changes to the experimental apparatus gave us more repeatable and reliable flow of the liquid hydrogen.

\section{EXPERIMENTAL CONSIDERATIONS}

As the liquid hydrogen fell toward the helium surface, it became frozen and particles formed immediately after hitting the helium surface. Some of the hydrogen froze as it fell, but some vaporized as well. The hydrogen was a jet of fluid, with the outer shear layer vaporizing, but with the central core remaining liquid for a short time, and finally freezing during the drop, and as it hit the helium surface.

During the fall of the hydrogen onto the helium, some of the hydrogen went into the gas phase. Small clouds of hydrogen were seen forming about the stream of hydrogen falling onto the free surface. Additional mass flow rate instrumentation was included to assess the total mass of hydrogen that is in the gas phase versus the solid particles. The temperature profiles of the dewar will shed light on the amount of gas formed, and a thermal and mass balance analysis can be conducted to more accurately measure the distribution of hydrogen gas and solid hydrogen in the dewar. A mass spectrometer was also used to determine the mass of hydrogen in the helium gas above the liquid helium.

Solid hydrogen is less dense than helium, so the hydrogen particles floated on the surface, simplifying the particle imaging. In an operational propulsion 
system, this buoyancy property will be overcome by gelling the helium, thus allowing the hydrogen particles to be suspended in the helium. During the testing, it was noted that the frozen hydrogen particles may also serve as an effective gelling agent for liquid helium.

A more detailed listing of the events from each run are provided in Appendix A. Appendix B and Figure 5 show typical images from the testing. The small particles were allowed to float on the helium surface for at least 25 minutes before adding more hydrogen. During that 25 minute minimum time span, they began to seek each other out, agglomerate into a larger collection of particles, and minimize their surface energy as they float on the helium. The particles also turned from clear or translucent crystals to cloudy crystals, implying a transition from face centered cubic (FCC) to hexagonal close pack (HCP) molecule packing (Ref. 13). After allowing the first batch of particles to form, the dewar pressure was lowered to agitate the liquid helium surface, and the particles quickly broke up into their original smaller components. The particles would then again begin to agglomerate.

Table II.-Solid hydrogen video event timing

02-23-2001: During the run, the helium level is between 14 and 16 inches below the lid.

12:14:44 The first drop begins

02-27-2001: During the run, the helium level is between 14 and 16 inches below the lid.

$14: 53: 46$

The first drop begins

\section{$\underline{\text { SOLID HYDROGEN TESTING RESULTS }}$}

Three major observations resulted from these solid hydrogen particle runs: particle sizes, the flows into and out of the dewar, and the particle formation efficiencies. Additional observations had to do with the thermal profile and stratification in the helium dewar.

\section{Analysis Background}

The images were taken with a 0.5 inch lens, charged coupled device (CCD) black and white camera. The illumination in the Dewar was created with 150 Watt bulb with the light introduced into the dewar with an optical fiber system. All of the observations were done with a black and white video camera, with a 56 degree field of view. The video images were recorded on Betacam and VHS tape formats. The Betacam recordings were used to improve the ability to obtain high definition frames for analysis. To analyze the particles, a commercially available photo manipulation and analysis software package was used.

There was one effective height to the liquid level that were used in the image analyses. The level for the helium was during the runs $(\mathrm{x} / \mathrm{L}=0.5,14$ inches below the lid), and this height was used for the baseline sizes for the overall image area (representing the entire free surface helium in the dewar). The specific particle sizes were then measured, and the ratio of the two, with the overall dewar surface area, is used to compute the particle size.

\section{Particle sizes}

The solid hydrogen particles were analyzed by digitizing the video images, and measuring the sizes of the particles. The particle size measurements were corrected for the actual size of the particles using these equations:

area, particle $=$ (area, dewar $/$ pixels, dewar) $\mathrm{x}$ pixels, particle

where:

area, particle $=$ area of the particle $\left(\mathrm{mm}^{2}\right)$

area, dewar $=$ area of the dewar free surface $\left(\mathrm{mm}^{2}\right)$

pixels, dewar $=$ number of pixels in the imaged free surface

pixels, particle $=$ number of pixels in the imaged particle

At the beginning of and during each run, a variety of individual particles are measured. The smallest of the particles is identified, as well as a representative set of other larger particle sizes. Figure 5 illustrates a typical image from the analyses. The circle encompasses a small set of hydrogen particles that have agglomerated.

Appendix A contains the raw data of the video observations from the 2001 testing and Appendix B provides the 2001 video image data. These data are the raw measurements of the particle sizes from the video observations.

In the Phase II tests, the smallest particles were formed during the initial freezing of the hydrogen. Figure 7 provides data from the 2001 testing. The smallest particle sizes are 1.0 to $6.4 \mathrm{~mm}$. In this testing, no control was placed on the particle formation, other than the helium and hydrogen temperature and pressure and the flow rate of the hydrogen. The simple freezing process is somewhat random, and the particle will vary in size simply due to the random breakup of the stream of hydrogen that fell onto the helium during the 
freezing process. The other measurement variation of the particles from the video images that occurred was that all of the particles were not perfectly spherical or elliptical, thus an average size was measured. The Phase II (2001) testing included some unique observations, such as tiny scintillating particles, curling up in strings to form larger millimeter sized particles.

\section{Flow out of the dewar}

The flow meter at the exit of the dewar exhaust stack records the volumetric flow rate out of the dewar. Figure 8 shows a flow rate versus time plot for a 2 second run, on 02-23-2001. Figure 9 provides similar data for the run of 02-27-2001. The total outflow mass for the 2 runs is quite different, and dependent upon the dewar gas temperature, and the conditions for each run.

The time for the flow rate to settle was about 2 minutes. The view on the camera however shows that the view remains cloudy, and does not clear for 21 minutes with the 02-23-2001 run, and 13 minutes with the 02-27-2001 run. The temperature in the helium dewar for the 2 runs is shown in Figure 4. The dewar liquid and gas temperature was generally lower in the run on 02-27-2001. However, the lid temperature was higher for this run.

\section{Flow into the dewar}

During the range of runs conducted in the 2001 Phase II test, the mass flow rate of liquid hydrogen into the dewar is maintained for 1 to 3 seconds. The nominal flow rate desired was $1 / 500$ th to $1 / 100$ th liter per second. These flow rate correspond to the precision flow valve being 15 and 30 percent open, respectively. Based on the calibration of the precision control flow valve, the flow rate is not linear, but somewhat sharply peaked. Figure 10 shows the notional comparison of the planned flow rate and Figure 11 depicts the typical valve percent open data from the liquid hydrogen valve, and it is related to actual flow rate from the test configuration. The instantaneous flow rate is therefore significantly different than the planned rate, and this difference led to creating a better planning for conducting the experiments. Average flow rates were not able to be used in the calculations but an integrated total mass of liquid hydrogen flow could be estimated.

\section{Particle formation efficiency}

The efficiency (eta) of particle formation can be expressed as:

Eta $=$ mass of hydrogen frozen / total mass of hydrogen (frozen plus vented)
From the analyses of the test images, the mass of frozen hydrogen was estimated (using the technique discussed in Ref. 10). The area of the hydrogen particle is used with the average thickness (of $4 \mathrm{~mm}$ ) of the hydrogen particle on the liquid helium to compute a hydrogen volume. A hydrogen density of $90 \mathrm{~kg} / \mathrm{m}^{3}$ was used for the analyses. This density was selected based on testing conducted by the USAF (Ref. 28). In the data from the run on 02-23-2001, the mass of hydrogen that was frozen was 2.55 grams. The hydrogen mass frozen in the run on $02-27-2001$ was 1.32 grams.

For the testing on the run on 02-23-2001, the efficiency (eta) was:

Eta $=2.55 /(2.55+1.1464)=0.69$ or 69 percent

The efficiency for the run on 02-27-2001 is

Eta $=1.32 /(1.32+0.695)=0.66$ or 66 percent

Comparing the frozen mass with the mass lost out of the dewar, is appears that the efficiency of production is somewhat low. For a small scale system, it may be typical to assume that that the efficiency of production may be low. In this experimental configuration, there is a relatively static production of solid hydrogen. There is little of no flow of the solid hydrogen particles away from the main formation point, and hence there is no way to demonstrate that a continuous production rate would be more efficient.

There is a large volume of warm gas above the liquid helium surface, which will tend to vaporize part of the liquid hydrogen, and make it unavailable for forming a solid. In many cases during formation, we see particles that have frozen onto the sides of the dewar, and slump into the liquid helium. Some of these particles are exceedingly small (much less than $1 \mathrm{~mm}$ diameter), and are hard to see directly. They reflect so much light they seem to scintillate, and the brightness obscures their direct observation.

The large gas volume above the liquid helium was required for the camera that was chosen for the testing. Filling to a higher level in the dewar does not allow us to image the full liquid helium surface. Without seeing the full surface or the full mass of frozen hydrogen, we are unable to predict the particle sizes, and observe and ultimately measure the full mass of frozen hydrogen.

Much of the gas that was obscuring the view is finally the frozen onto the walls, and becomes the tiny scintillating particles. This seems evident from the observations for longer flow times, and higher flow rates. 


\section{Timing event influence}

During the testing there are several time scales that affect the solid hydrogen formation. The first is the time of flow for the liquid hydrogen, the second the time for the hydrogen outflow to be completed, and the time for the gas in the ullage to liquefy, and then solidify. There are different time scales for the different processing to occur. The flow of liquid hydrogen in the tank is about 1 to 4 seconds, the time for the outflow to stabilize is about 60 seconds, and the time for the freezing of the hydrogen gas in the dewar ullage is about 1 to 30 minutes.

The flow of liquid hydrogen is controlled by the precision flow rate hydrogen valve and the pressure difference across it. This flow rate is computed using standard techniques. During the testing, care was taken to prevent the hydrogen tank pressure from exceeding the helium dewar pressure. A small amount of unplanned leakage of hydrogen into the helium dewar, creating particles before an experimental run was planned to begin.

The freezing of the ullage gas was influenced by the rate of flow into the dewar, and the temperature of the dewar ullage gas. These values can be controlled more rigorously in future experiments, but they were not controlled precisely in these experimental runs.

\section{COMPARISON OF PHASE I AND PHASE II TESTING}

There were some interesting similarities and differences between the Phase I and Phase II testing. Figure 12 shows the Phase I (1999) particle sizes results. Overall, the initially formed particles were 1.8 to $4.6 \mathrm{~mm}(0.07$ to 0.18 inches) in diameter. These sizes are very similar to those from Phase II: 1.0 to $6.4 \mathrm{~mm}$.

Particle compaction was found in this set of experimental runs, as with the Phase I testing in 1999. The compaction trends seen in the Phase I and Phase II testing were similar. The smallest particle sizes were very small (almost microscopic) in most cases, and much smaller than those seen in Phase I. The lower dewar temperatures were able to freeze particles onto the walls of the dewar, and these particles flow down the walls and enter the liquid helium.

Many additional images and other temperature data are available for analyses, and these additional images and data can lead us to more insights into the formation process. Initial analyses of the video and flow rate data showed many new phenomena that were not previously observed. These phenomena include the formation of what appear to be microscopic hydrogen particles, the formation of long coiled structures of hydrogen that curl up to form small particles, and the formation of long bars of solid hydrogen. Additional data and video analyses will show the precise conditions under which the new phenomena occur.

\section{CONCLUSIONS}

The solid hydrogen testing described in this paper was the Phase II testing of a program to characterize solid hydrogen particles. The improvements to the test article allowed a better measurement of the flow rate into and out of the dewar. These measurements allowed the computation of a production efficiency, and showed that the formation efficiency is related to many aspects of the event timing for the experiment.

The particle sizes formed in the Phase I (1999) and the Phase II (2001) testing were of very similar sizes. In the Phase I (1999) tests, the sizes ranges from 1.8 to $4.6 \mathrm{~mm}$ in diameter. The Phase II (2001) testing produced particle sizes of 1.0 to $6.4 \mathrm{~mm}$. However, there were many more interesting phenomena that occurred in the freezing processes in Phase II. These phenomena included microscopic scintillating particles, and particle that froze onto the dewar walls and slid into the liquid helium.

The particle formation efficiency is in the range of 66 to 69 percent for the 2 runs analyzed. This efficiency though relatively low, shows that a large fraction of the hydrogen is frozen. However, for future propulsion systems, a better method of particle formation is needed. Using recirculation systems, recovery and reuse of the vented hydrogen is likely.

\section{$\underline{\text { CONCLUDING REMARKS }}$}

The data analyzed thus far shows that the formation process must be done slowly to allow for the most efficient solid hydrogen particle formation. A fast flow will create a large cloud of hydrogen, much of which will go out of the vent stack. Additional experiment analyses will reveal the best flow rates from these experiments.

Future propulsion systems using atomic rocket propellants with solid hydrogen will likely require massive facilities for creating particles and many complex processes to trap atoms. Though the complexities seem daunting, the potential of these propellants is great, and the capacity for reducing vehicle lift off weight and increasing payload capacity is theoretically unmatched. In some future vehicles and energy systems, atomic propellants in solid hydrogen 
may allow us to store and controllably release large quantities of energy, and allow the final Human expansion into the Solar System.

\section{REFERENCES}

1) Palaszewski, B., "Atomic Hydrogen Propellants: Historical Perspectives and Future Possibilities," NASA Lewis Research Center, AIAA 93-0244, NASA TM-106053, presented at the 31st AIAA Aerospace Science Meeting, Reno, NV, January 11-14, 1993.

2) Palaszewski, B., Ianovski, L., and Carrick, P., "Propellant Technologies: Far Reaching Benefits for Aeronautical and Space Vehicle Propulsion," in the Special Edition of the AIAA Journal of Propulsion and Power, September/October 1998, pp. 641-648.

3) Palaszewski, B., "Launch Vehicle Performance for Bipropellant Propulsion using Atomic Propellants with Oxygen," NASA Glenn Research Center at Lewis Field, AIAA 99-2837, presented at the 35th AIAA/ASME/SAE Joint Propulsion Conference, Los Angeles, CA, June 1999.

4) Palaszewski, B., "Launch Vehicle Performance with Solid Particle Feed Systems for Atomic Propellants," AIAA 98-3736, NASA/TM-1998208498, presented at the 34th AIAA/ASME/SAE Joint Propulsion Conference, Cleveland, OH, July 1998.

5) Palaszewski, B., "Solid Hydrogen Testing and Analyses for Atomic Rocket Propulsion," presented to the Propulsion Engineering Research Center (PERC) $11^{\text {th }}$ Annual Symposium on Propulsion, The Atherton Hotel, State College, PA, November 18-19, 1999.

6) Palaszewski, B., "Atomic Propellants for Aerospace Propulsion Systems: Solid Hydrogen Experiments and Vehicle Analyses," presented at the 1999 USAF High Energy Density Materials Contractors Conference, Cocoa Beach, FL, June 810, 1999.

7) Palaszewski, B., "Atomic Hydrogen as a Launch Vehicle Propellant," NASA Lewis Research Center, AIAA 90-0715, NASA TM-102459, presented at the 28th AIAA Aerospace Science Meeting, Reno, NV, January 8-11, 1990.

8) Lubell, M., Lue, J., and Palaszewski, B., "LargeBore Superconducting Magnets for High Energy Density Propellant Storage," presented at the 1996 Applied Superconductivity Conference, Pittsburgh, PA, August 25-30, 1996.
9) Palaszewski, B., "Solid Hydrogen Experiments for Atomic Propellants," NASA Glenn Research Center at Lewis Field, AIAA 2000-3855, presented at the 36th AIAA/ASME/SAE Joint Propulsion Conference, Huntsville, AL, July 2000.

10) Palaszewski, B., "Solid Hydrogen Experiments for Atomic Propellants: Image Analyses," NASA Glenn Research Center at Lewis Field, AIAA 2001-3233, presented at the 37th AIAA/ASME/ SAE Joint Propulsion Conference, Salt Lake City, UT, July 2001.

11) Sanger, E., Rocket Flight Engineering, NASA Technical Translation, NASA TT-F-223, Translation Into English of the book "Raketenflugtechnik" Berlin, Verlag Von Oldenburg, 1933, translation published September 1, 1965.

12) Dempsey, P., and Stochl, R., "Supplemental Multilayer Insulation Research Facility," NASA Lewis Research Center, NASA TM-106991, July 1995.

13) Silvera, I., "The Solid Molecular Hydrogens in the Condensed Phase: Fundamentals and Static Properties," Reviews of Modern Physics, Vol. 52, No. 2, Part I, April 1980, pp. 393-452.

14) McCarty, R.D., "Hydrogen Technology Survey: Thermophysical Properties," National Bureau of Standards, NASA Technical Reports, NASA SP3089, January 1975.

15) Fajardo, Mario, USAF Research Laboratory, Edwards, CA, personal communication, July 1999.

16) McNellis, N., et al., "A Summary of the Slush Hydrogen Technology Program for the National Aero-Space Plane," NASA TM-106863, AIAA Paper 95-6056, presented at the Hypersonics Technologies Conference, Chattanooga, TN, April 3-7, 1995.

17) Hardy, T.L., "FLUSH: A Tool for the Design of Slush Hydrogen Flow Systems," Technical Memorandum, NASA TM-102467, Lewis Research Center, February 1, 1990.

18) Sater, J.D., Pipes, J., and Collins, G.W., "Cryogenic D-T Fuel Layers Formed in 1-mm Spheres by Beta-Layering," Report Number UCRL-JC-128031-ABS-REV-1, Lawrence Livermore National Laboratory, Target Fabrication Meeting '98, 1998.

19) Collins, G.W., Sanchez, J.J., Bernat, T., Sater, J.D., and Bittner, D., "Forming Uniform D-T and D2 Layers For Cryogenic NIF Targets," Report Number UCRL-JC-129969-ABS, Lawrence Livermore National Laboratory, European Conference on Laser Interaction with Matter, 1998. 
20) Bittner, D.N., Collins, G.W., Monsler, E., and Letts, S., "Forming Uniform HD Layers In Shells Using Infrared Radiation," Livermore National Laboratory, Report Number UCRL-JC-131371, 40th Annual Meeting of the Division of Plasma Physics, New Orleans, LA, November 16-20, 1998.

21) Collins, G.W., Bittner, D.N., Monsler, E., Letts, S., Tiszauer, D., Feit, M., Mapoles, E.R., and Bernat, T.P., "Forming and Smoothing D2 and HD Layers for ICF by Infrared Heating," Lawrence Livermore National Laboratory, Report Number UCRL-JC123596-ABS, European Conference on Laser Interaction with Matter, 24th, Madrid, Spain, June 3-7, 1996.

22) Collins, G.W., Mapoles, E.R., Sanchez, J.J., Bernat, T., Sater, J.D., Bittner, D., Sheliak, J.D., Hoffer, J.K., "Reducing DT Surface Roughness For Cryogenic Ignition Targets," Lawrence Livermore National Laboratory, Report Number UCRL-JC-124884-ABS, Annual Meeting of the American Physical Society Division of Plasma Physics, 38th, Denver, CO, November 11-15, 1996.

23) Kozioziemski, B.J., Collins, G.W., and Bernat, T.P., "Single Crystal Growth of Solid D2," Lawrence Livermore National Laboratory, Report Number UCRL-JC-125981-ABS, 1997 March Meeting of the American Physical Society, Kansas City, MO, March 17-21, 1997.

24) Kozioziemski, B.J., Collins, G.W., Bernat, T.P., Mapoles, E.R., and Unites, W., "Crystal Growth And Roughening Of Solid D2," Lawrence Livermore National Laboratory, Target Fabrication Specialist's Meeting, 11th, Orcas Island, WA, September 8-12, 1996, Report Number UCRLJC-125121-ABS, Fusion Technology, Vol. 31, pp. 482-484, July 1997.

25) Bittner, D.N., Collins, G.W., Letts, S., and Monsler, E., "Generation Of Uniform Solid HD Layers Inside Spherical Capsules Using Infrared Illumination," Lawrence Livermore National Laboratory, Report Number UCRL-JC-125140ABS, Conference, Target Fabrication Specialist's Meeting, 11th, Orcas Island, WA, September 8-12, 1996.

26) Bernat, T.P., Collins, G.W., Mapoles, E.R., and Duriez, C., "Heat-Flux Induced Changes To Multicrystalline D2 Surfaces," Lawrence Livermore National Laboratory, Report Number UCRL-JC-124261-ABS-REV-1, 39th Annual Meeting of the APS (American Physical Society)/DPP (Division of Plasma Physics), Pittsburgh, PA, November 17-21, 1997.
27) Kozioziemski, B.J., Collins, G.W., and Bernat, T.P., "D2 Crystal Growth and Surface Energy," Lawrence Livermore National Laboratory, Report Number UCRL-JC-130037-ABS, Target Fabrication Meeting '98, Jackson Hole, Wyoming, April 19-23, 1998.

28) Fajardo, M., "Cryosolid Propellants - The Last "Revolutionary" HEDM Concept," in Berman, M. (editor), Proceedings of the High Energy Density Matter (HEDM) Contractors Conference, Scientific Special, June 8-10, 1999, January 2000.

29) Larson, C.W., "Kinetics of Boron Carbon HEDM," in Berman, M. (editor), Proceedings of the High Energy Density Matter (HEDM) Contractors Conference, Scientific Special, June 8-10, 1999, January 2000.

30) Talroze, V.L., Gordon, E.B., Ivanov, B.I., Perminov, A.P., Ponomarev, A.N., "Measurement of the Hyperfine State of the Hydrogen Atom as it Interacts in the Gas Phase With $\mathrm{CO}, \mathrm{SO} 2, \mathrm{CO} 2$ and N2O Molecules," Akademiia Nauk SSSR Page: vol. 227, Akademiia Nauk SSSR, Doklady, vol. 227, Mar. 11, 1976, pp. 407-410. In Russian. Mar. 11, 1976, pp. 407-410. In Russian.

31) Gordon, E.B., Perminov, A.P., Ivanov, B.I., Matiushenko, V.I., Ponomarev, A.N., and Tal'roze, V.L., "Change In The Hyperfine State of the Hydrogen Atom During Its Collisions With Unsaturated Hydrocarbon Molecules in the Gaseous State," (Previously cited in issue 23, p. 3317, (Zhurnal Eksperimental'noi i Teoreticheskoi Fiziki, vol. 63, Aug. 1972, pp. 401406.) Soviet Physics - JETP, vol. 36, Feb. 1973, pp. 212-215. Translation.

32) Hardy, W.N., Klump, K.N., Schnepp, O., Silvera, I.F. "Optical Phonons in Solid Hydrogen and Deuterium in the Ordered State," Phys. Rev. Letters, Vol. 21, No. 5, July 29, 1968. pp. 291-294.

33) Agosta, C.C., Silvera, I.F, Stoof, H.T.C., and Verhaar, B.J., "Trapping Of Neutral Atoms With Resonant Microwave Radiation," Technische Univ., "Few-Body Collisions in a Weakly Interacting Bose Gas," reprinted from Physical Review Letters (American Physical Society), vol. 62, no. 20, 15 May 1989, pp. 2361-2364. 
Atomic hydrogen rockets: no helium addition

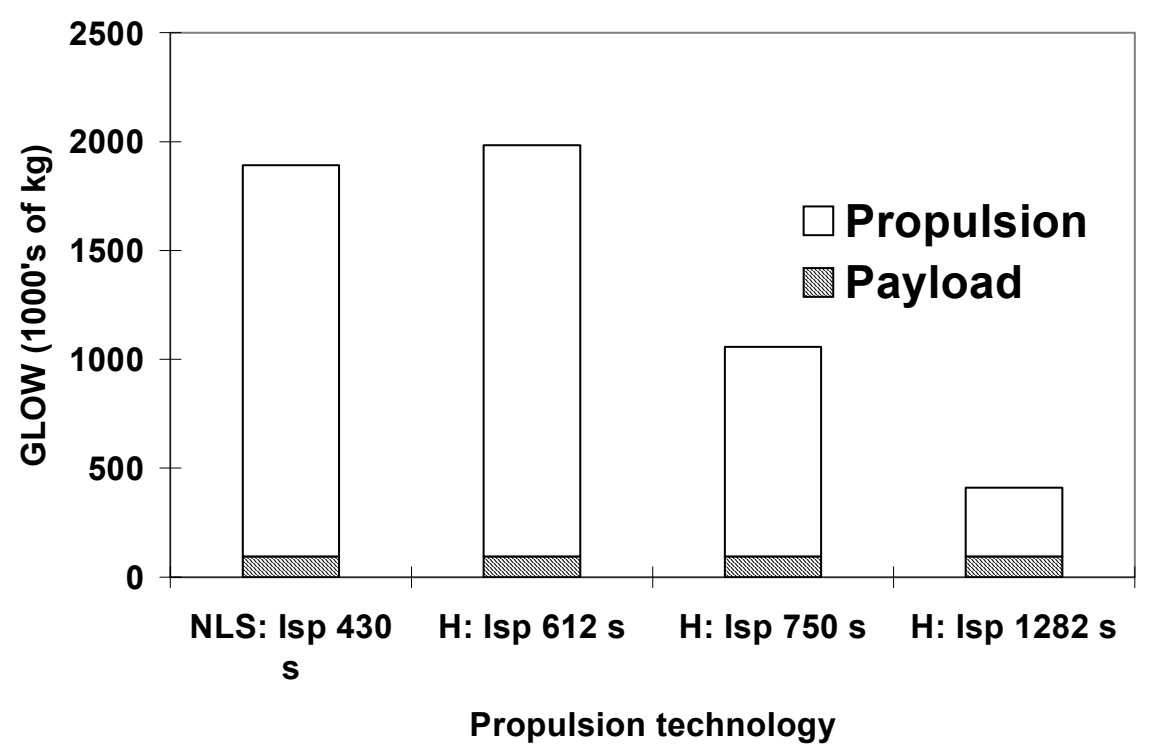

Figure 1. Atomic hydrogen rocket vehicle GLOW

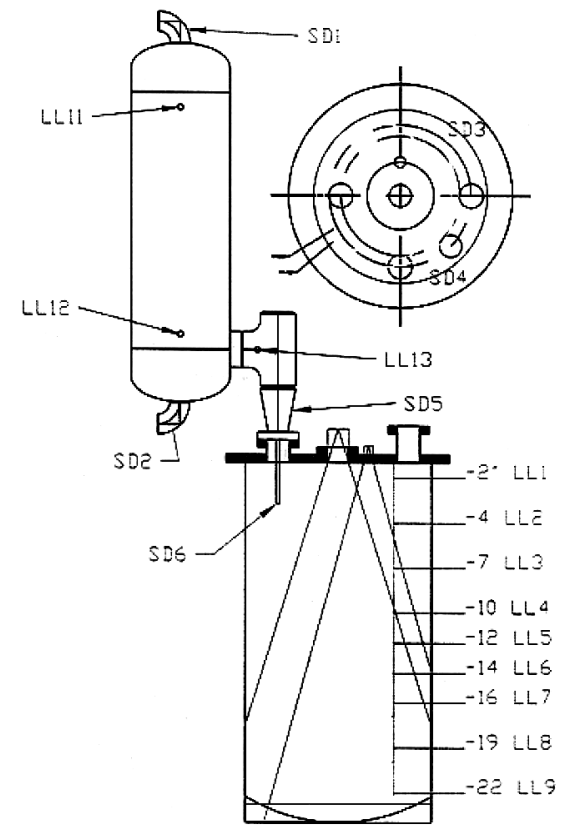

Figure 2. Solid hydrogen test configuration—Liquid helium dewar and liquid hydrogen tank 


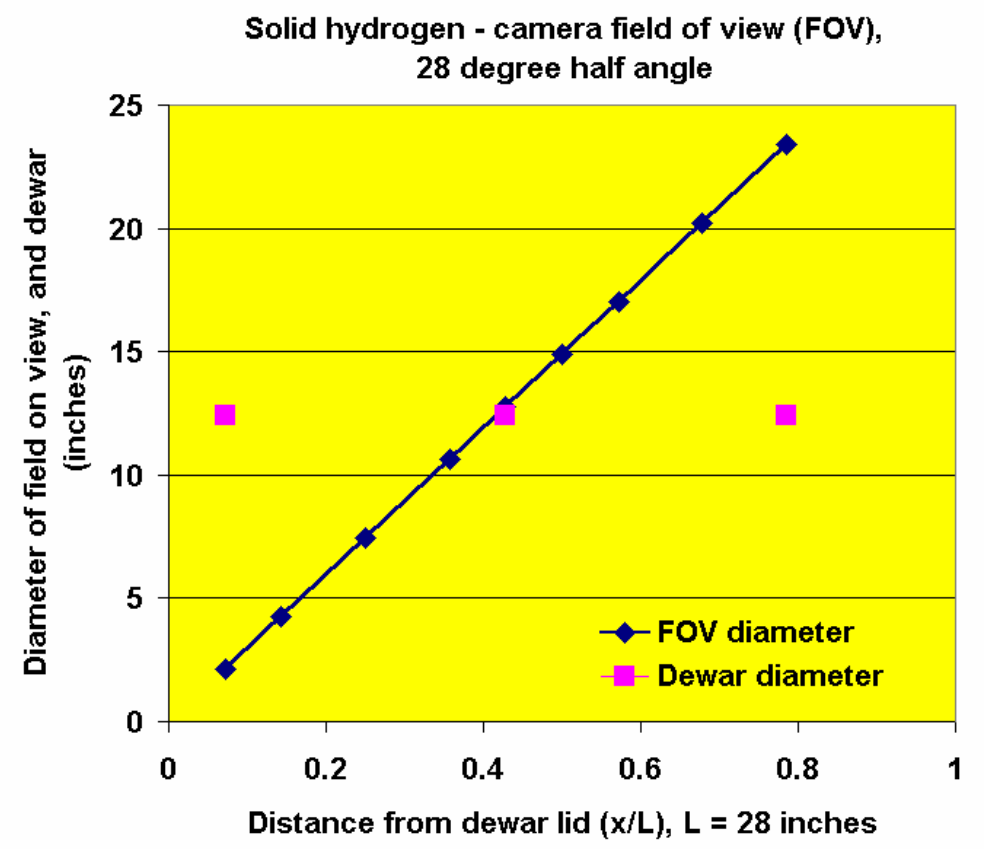

Figure 3. Solid hydrogen experiment: camera field of view (FOV), dewar diameter $=315.9 \mathrm{~mm}$

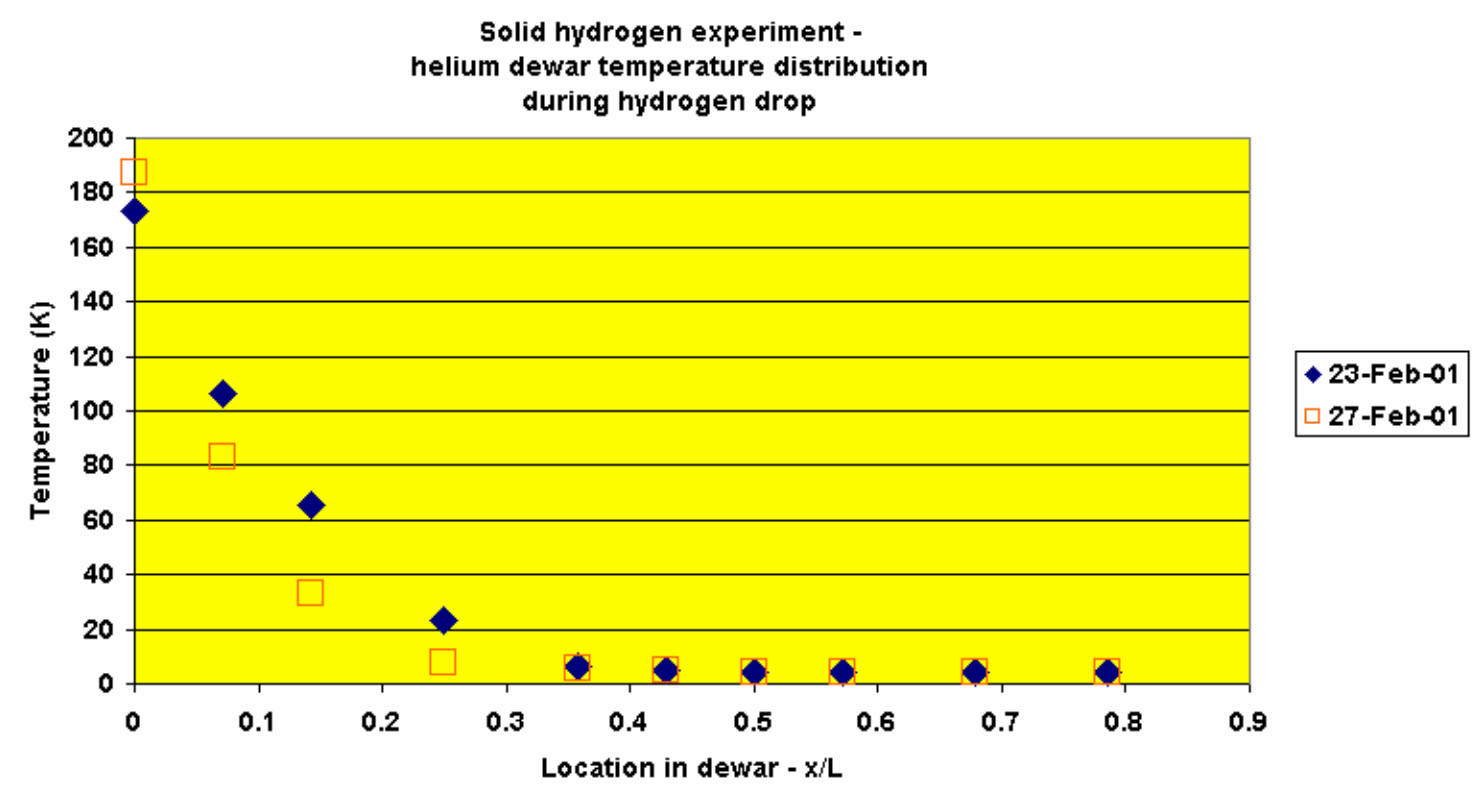

Figure 4. Temperature distribution in helium dewar: 02-23-2001 and 02-27-2001 


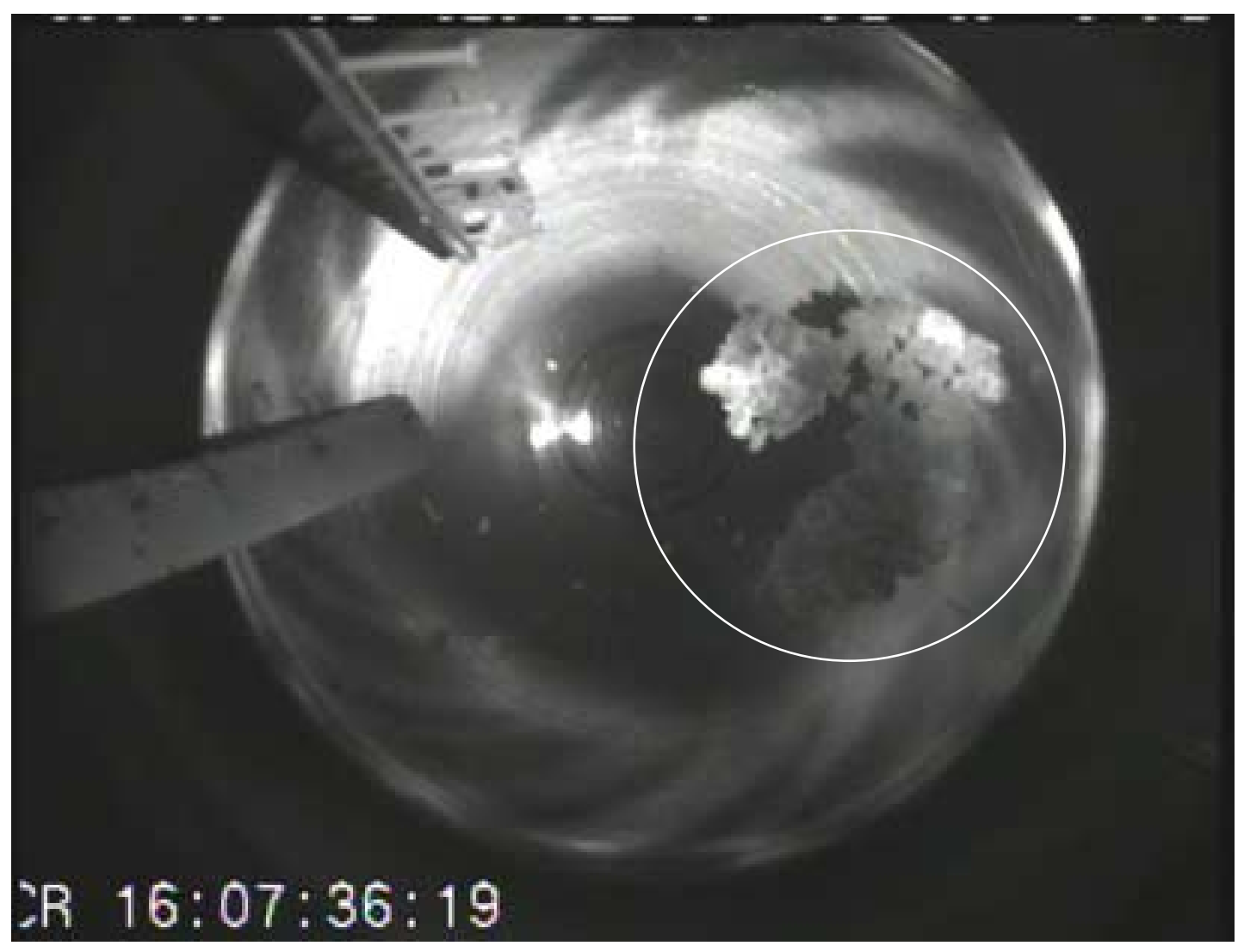

Figure 5. Image of solid hydrogen 2001 (full mass on helium surface)

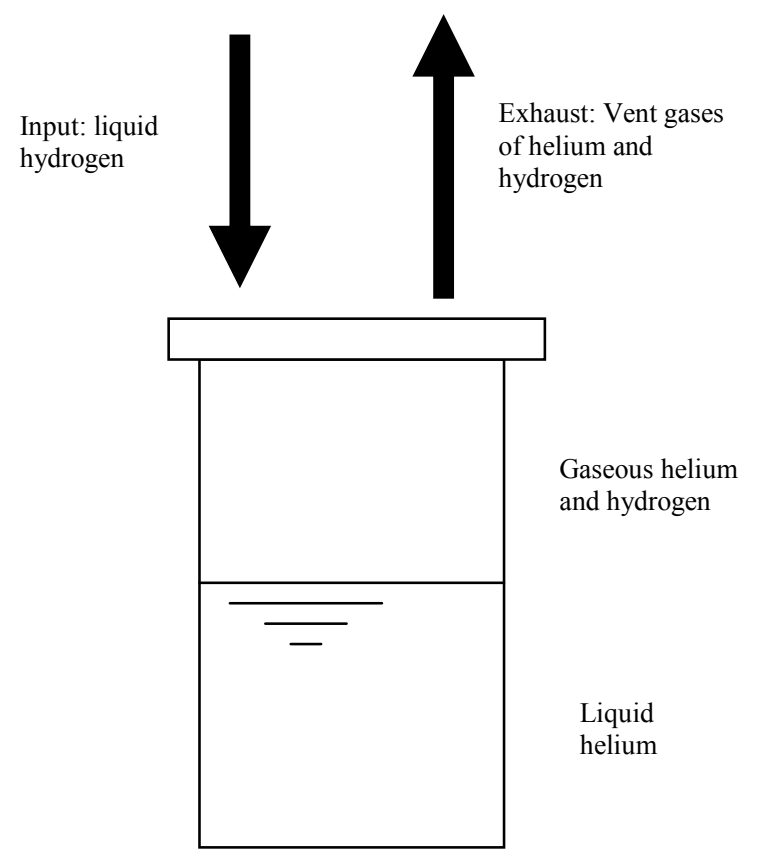

Figure 6. Flow in and out of the Helium Dewar 


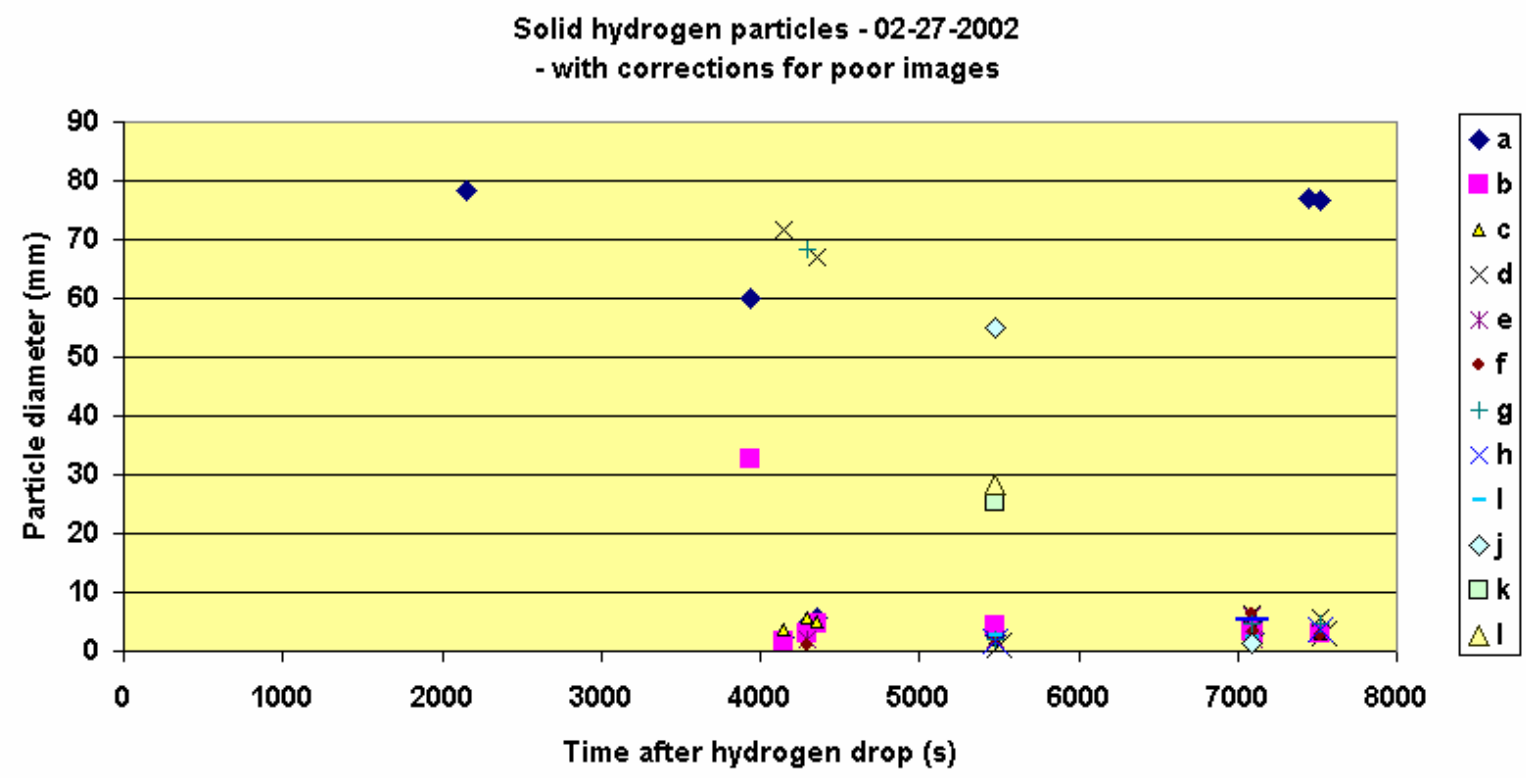

Figure 7. Solid hydrogen particle diameter versus time - Solid hydrogen run: 02-27-2002

Hydrogen vent - 02-23-2001

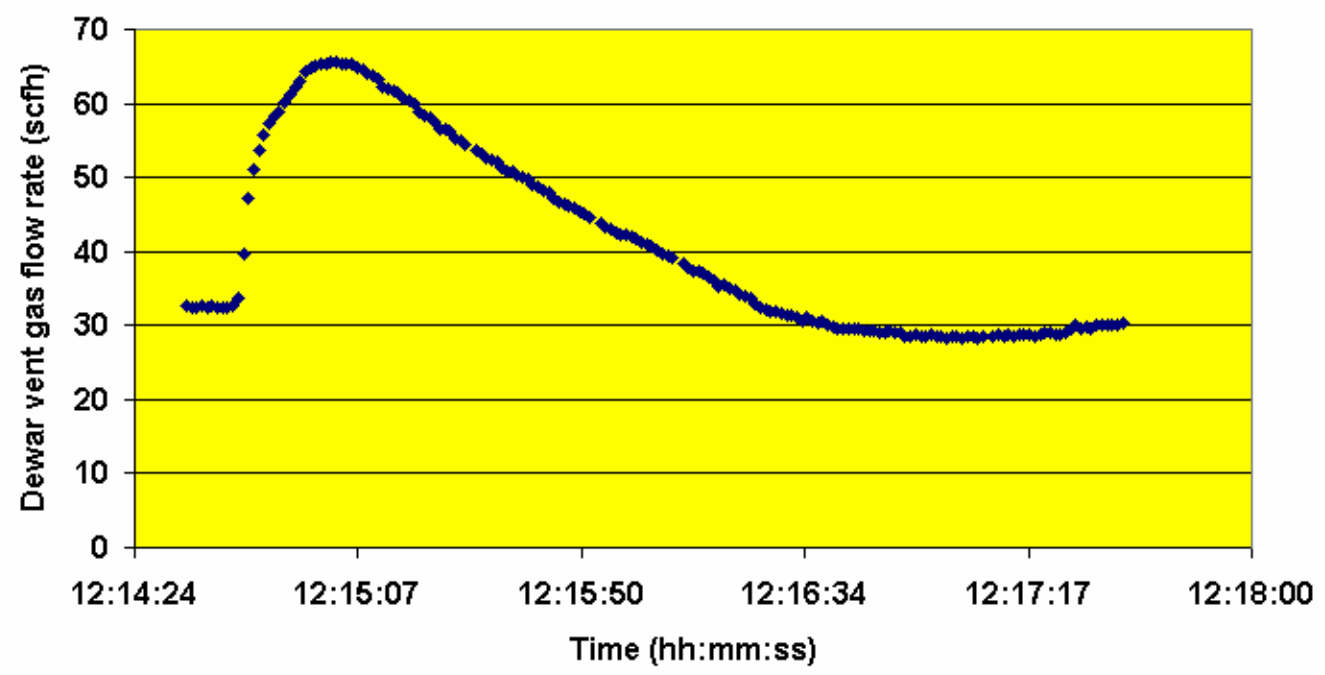

Figure 8: Gaseous hydrogen flow rate out of dewar: 02-23-2001 
H2 vent gases - 02-27-2002

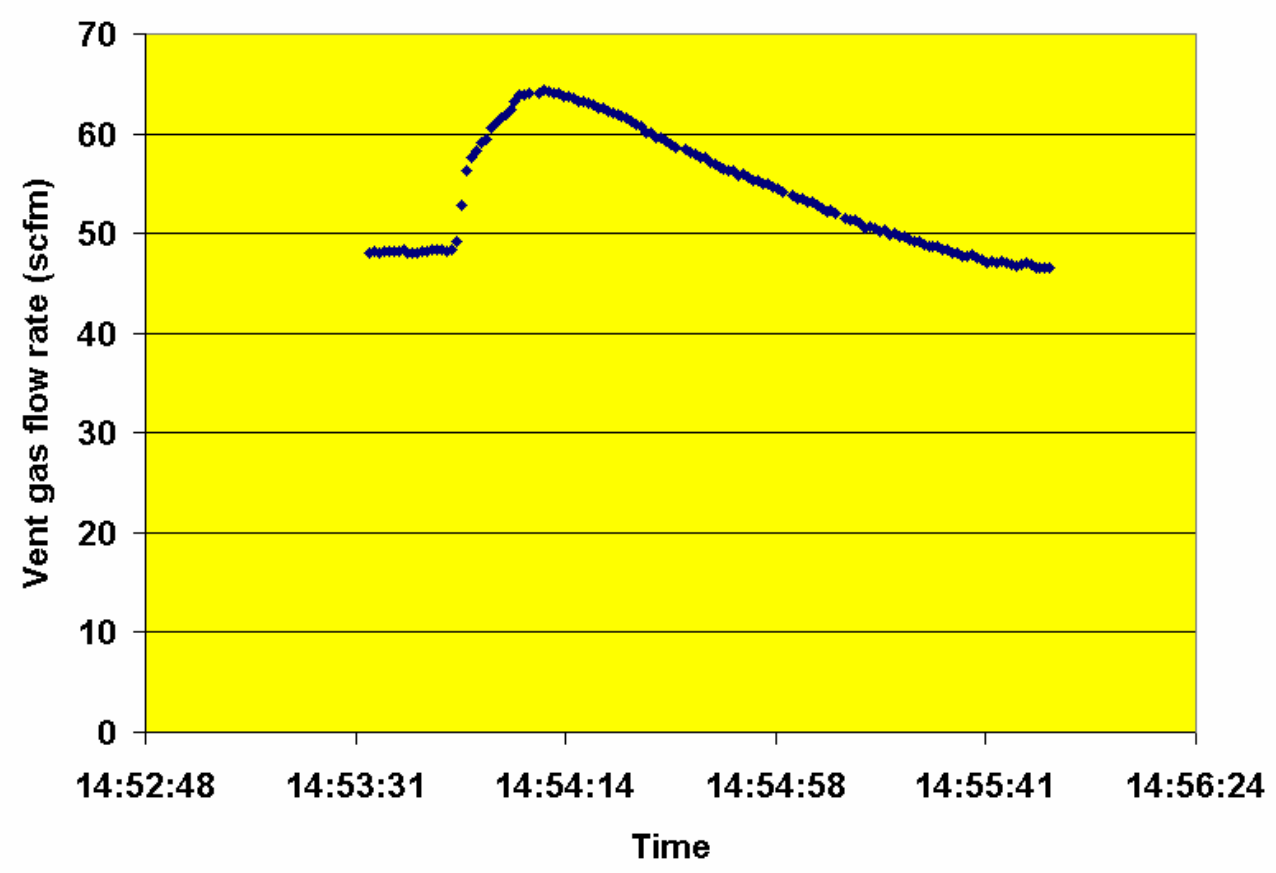

Figure 9: Gaseous hydrogen flow rate out of dewar: 02-27-2001

\section{Solid Hydrogen Testing : Liquid Hydrogen Mass Flow Rate}
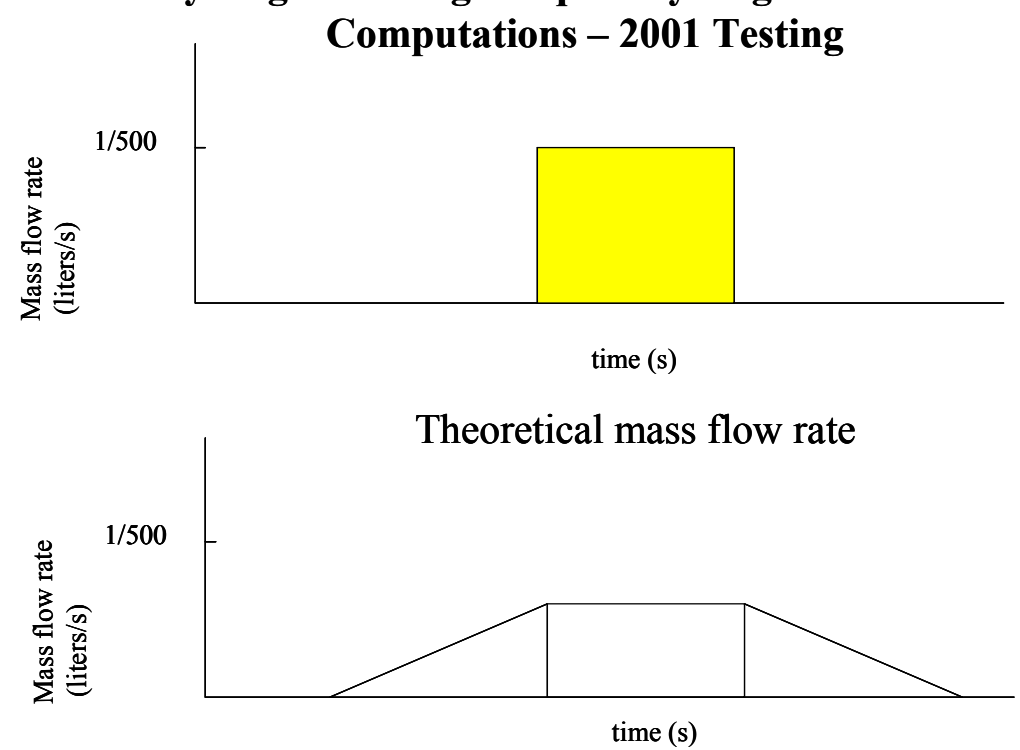

Planned experimental mass flow rate

Figure 10. Notional flow rate for solid hydrogen 


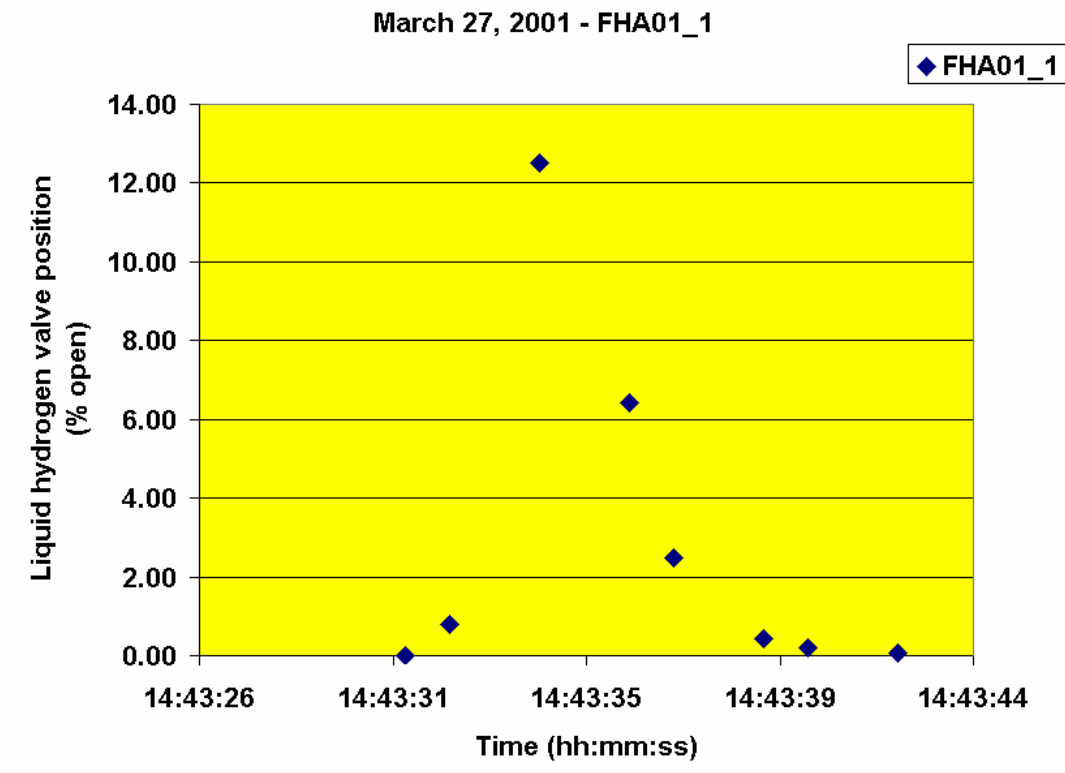

Figure 11. Liquid hydrogen valve opening versus time: for flow rate into helium dewar

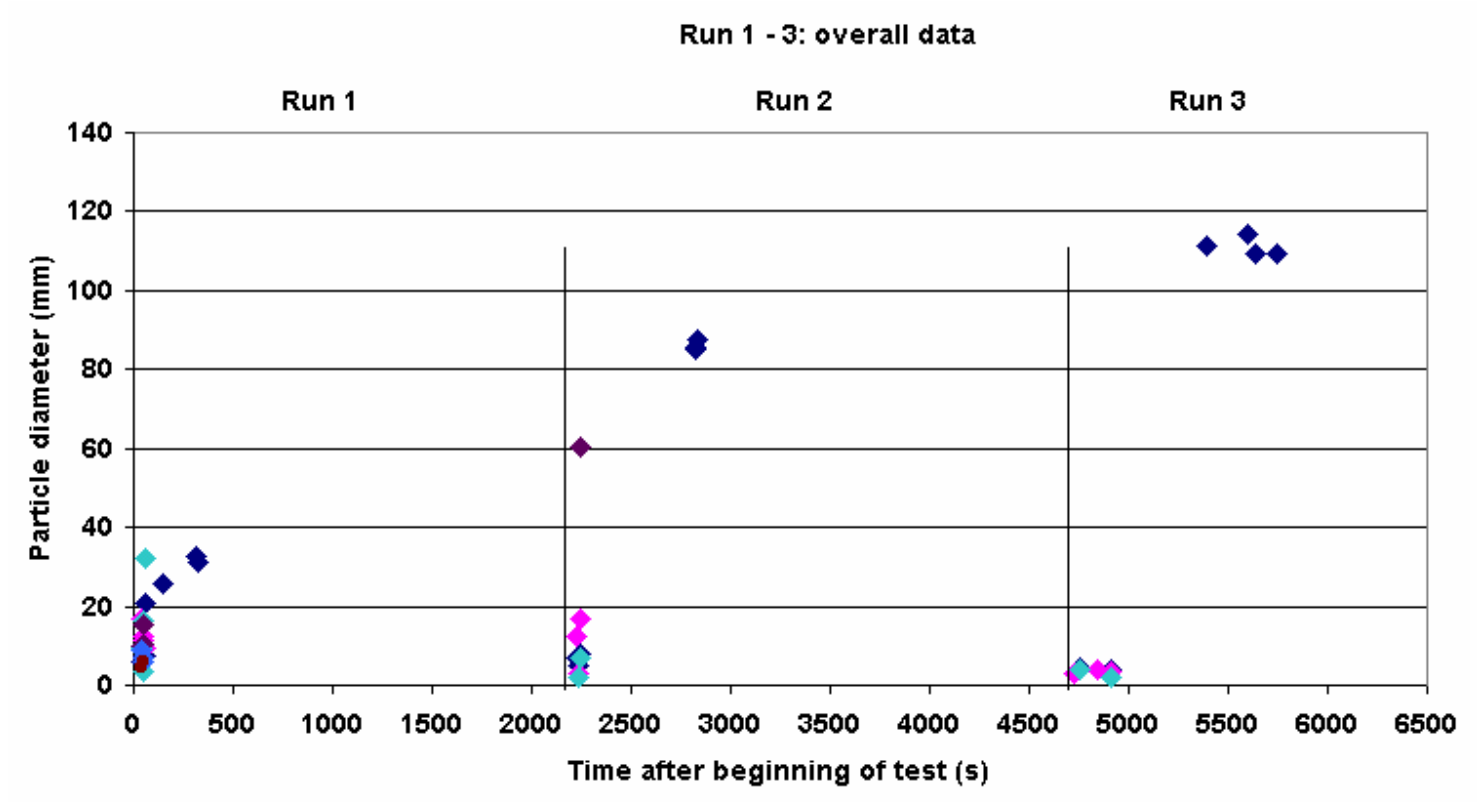

Figure 12. Solid hydrogen particle sizes, Phase I testing (1999) 
Appendix A

Solid Hydrogen Video Observations: February 27, 2001

Tape 1

\begin{tabular}{|c|c|}
\hline $\begin{array}{l}\text { Event timing } \\
\text { (hh:mm:ss:ff) }\end{array}$ & Observations \\
\hline $14: 48: 01: 25$ & $\begin{array}{l}\text { Beginning of tape. This is a null } \\
\text { image, before } 1^{\text {st }} \mathrm{H}_{2} \text { drop. Small } \\
\text { amount of boiling at } \\
\text { temperature rake }\end{array}$ \\
\hline \multirow[t]{2}{*}{ 14:48:59:05 } & Calm Helium surface. \\
\hline & $\begin{array}{l}\text { Liquid Helium level } \sim 16 " \\
\text { below lid }\end{array}$ \\
\hline $14: 53: 45: 16$ & $\begin{array}{l}\text { Begin drop of liquid } \mathrm{H} 2 \text { to form } \\
\text { solid hydrogen. Flow rate is } \\
\text { approximately } 1 / 100^{\text {th }} \text { liter } / \mathrm{sec} \text {, } \\
\text { t, open }=2 \mathrm{sec} \text { (corresponding to } \\
30 \% \text { open for } \mathrm{H} 2 \text { valve) }\end{array}$ \\
\hline 14:53:50:03 & $\begin{array}{l}\text { Clouds form, but many particles } \\
\text { are visible (through the clouds) }\end{array}$ \\
\hline 14:54:05:12 & Many small particles visible \\
\hline 14:54:22:09 & $\begin{array}{l}\text { Flurries of small particles, but } \\
\text { very cloudy.... }\end{array}$ \\
\hline $14: 54: 41: 22$ & $\begin{array}{l}\text { Large agglomerate to visual } \\
\text { rake. Very cloudy, but clearing } \\
\text { up. }\end{array}$ \\
\hline 14:58:07:11 & $\begin{array}{l}2 \text { tiny particles swirl at center of } \\
\text { field of view (FOV) }\end{array}$ \\
\hline \multirow[t]{2}{*}{$15: 01: 26: 13$} & $\begin{array}{l}\text { Fog about } 1 / 2 \text { gone, agglomerate } \\
\text { is quite visible, attached to } \\
\text { visual. Rake... }\end{array}$ \\
\hline & $\begin{array}{l}\text { Much of it is out of FOV } \\
\text { (agglomerate not visible, fully) }\end{array}$ \\
\hline $15: 06: 22: 27$ & $\begin{array}{l}\text { Boiling visible off of } \\
\text { temperature rake }\end{array}$ \\
\hline 15:10:30:06 & $\begin{array}{l}\text { Fog mostly cleared up, } \\
\text { agglomerate is unmoving }\end{array}$ \\
\hline $15: 21: 55: 16$ & $\begin{array}{l}\text { Agglomerate is still } \\
\text { immobilized }\end{array}$ \\
\hline
\end{tabular}

\begin{tabular}{|l|l|}
\hline 15:28:10:21 & $\begin{array}{l}\text { Agglomerate moves, dropped } \\
\text { pressure in dewar } 1 / 4 \text { psia to } \\
\text { attempt to move agglomerate } \\
\text { (at } \sim 15: 27: 00)\end{array}$ \\
\hline $15: 28: 37: 15$ & $\begin{array}{l}\text { Agglomerate breaks loose, but } \\
\text { reattaches to visual rake. } \\
\text { Reduce pressure in dewar. } \\
\text { another 1/4 psia (at } ~ 15: 29: 00)\end{array}$ \\
\hline $15: 29: 28: 04$ & $\begin{array}{l}\text { Agglomerate begins rotating } \\
\text { about the visual rake. }\end{array}$ \\
\hline $15: 29: 24: 27$ & $\begin{array}{l}\text { good image of complete mass of } \\
\text { solid H2 }\end{array}$ \\
\hline $15: 31: 01: 22$ & $\begin{array}{l}\text { Good image of ice edges } \\
\text { Agglomerate is arrested by } \\
\text { visual rake in new configuration }\end{array}$ \\
\hline $15: 32: 25: 10$ & $\begin{array}{l}\text { More boiling at bottom of } \\
\text { dewar, Lower pressure again to } \\
\text { dislodge solid H2 }\end{array}$ \\
\hline $15: 36: 42: 27$ & $\begin{array}{l}\text { More violent boiling dislodges } \\
\text { solid H2 }\end{array}$ \\
\hline $15: 37: 03: 07$ & $\begin{array}{l}\text { Agglomerate is almost } \\
\text { completely in FOV }\end{array}$ \\
\hline $15: 37: 48: 02$ & $\begin{array}{l}\text { Agglomerate is back in FOV in } \\
\text { new configuration }\end{array}$ \\
\hline $15: 41: 09: 11$ & $\begin{array}{l}\text { Agglomerate moves OUT of } \\
\text { FOV }\end{array}$ \\
\hline $15: 42: 44: 06$ & $\begin{array}{l}\text { Agglomerate moving due to } \\
\text { induced boiling }\end{array}$ \\
\hline $15: 43: 50: 16$ & $\begin{array}{l}\text { Part of agglomerate (that is free } \\
\text { floating) has dark \& light } \\
\text { sections }- \text { good for study }\end{array}$ \\
\hline End of tape \\
\hline $15: 44: 30: 22$
\end{tabular}


Tape 2

\begin{tabular}{|c|c|c|c|}
\hline $\begin{array}{l}\text { Event timing } \\
\text { (hh:mm:ss:ff) }\end{array}$ & Observations & 16:07:36:19 & $\begin{array}{l}\text { MANY New Tiny Particles } \\
\text { Everywhere }\end{array}$ \\
\hline $15: 44: 54: 04$ & $\begin{array}{l}\text { Beginning of tape, solid } \mathrm{H} 2 \\
\text { still arrested by visual rake }\end{array}$ & \multirow[t]{2}{*}{$16: 12: 06: 23$} & \multirow{2}{*}{$\begin{array}{l}\text { MANY tiny particles } \\
\text { persist, do not appear to be } \\
\text { agglomerating }\end{array}$} \\
\hline \multirow{3}{*}{$15: 46: 51: 11$} & \multirow{3}{*}{$\begin{array}{l}\text { Boiling evident from } \\
\text { lowered P., Solid } \mathrm{H} 2 \text { is } \\
\text { tenaciously hanging on, } \\
\text { only small portion is } \\
\text { moving. }\end{array}$} & & \\
\hline & & $16: 12: 50: 10$ & $\begin{array}{l}\text { Particle appear to repel } \\
\text { each other, HUMM! }\end{array}$ \\
\hline & & $16: 13: 15: 28$ & $\begin{array}{l}\text { Lower pressure to break up } \\
\text { solid H2 - KA Boom! }\end{array}$ \\
\hline 15:51:00:09 & $\begin{array}{l}\text { *Piece breaks free to } \\
\text { circulate on surface }\end{array}$ & $16: 13: 46: 18$ & Good edge of FOV \\
\hline \multirow[t]{2}{*}{ 15:52:14:05 } & \multirow{2}{*}{$\begin{array}{l}\text { Good image for aging } \\
\text { study (light and dark area } \\
\text { to be calculated). }\end{array}$} & $16: 15: 27: 00$ & $\begin{array}{l}\text { Many smaller agglomerates } \\
\text { dance...... }\end{array}$ \\
\hline & & \multirow[t]{3}{*}{$16: 22: 29: 00$} & $1 /[1 / 23 / 2002]$ \\
\hline $15: 54: 32: 17$ & $\begin{array}{l}\text { Another good image for } \\
\text { aging study... }\end{array}$ & & \multirow{2}{*}{$\begin{array}{l}\text { Particles move slowly, not } \\
\text { fully agglomerated, mass } \\
\text { of } \mathrm{H} 2 \text { by rake (visual) and } \\
\text { one in open space }\end{array}$} \\
\hline $15: 54: 40: 28$ & $\begin{array}{l}\text { *Piece rejoins larger } \\
\text { agglomerate... }\end{array}$ & & \\
\hline $15: 55: 37: 00$ & Static, Clam View & $16: 25: 05: 22$ & $\begin{array}{l}\text { Many tiny (super tiny) } \\
\text { particles, dead center, FOV }\end{array}$ \\
\hline $15: 55: 38: 29$ & $\begin{array}{l}\text { *Piece moves up, out of } \\
\text { fov }\end{array}$ & $16: 27: 20: 26$ & More tiny particles \\
\hline \multirow[t]{2}{*}{$15: 56: 31: 27$} & \multirow{2}{*}{$\begin{array}{l}\text { Lower pressure to agitate } \\
\text { complete agglomerate, } \\
\text { breaking it up. } \\
{[\mathrm{D}, \mathrm{FOV} \sim 113 / 8 \text { "] }}\end{array}$} & $16: 29: 33: 24$ & $\begin{array}{l}\text { Many tiny particles scoot } \\
\text { about the surface }\end{array}$ \\
\hline & & $16: 31: 55: 05$ & $\begin{array}{l}\mathrm{H} 2 \text { mass from visual rake } \\
\text { breaks away }\end{array}$ \\
\hline 15:56:47:03 & Edge of FOV & $16: 33: 10: 10$ & $\begin{array}{l}\text { More motion on helium } \\
\text { surface... }\end{array}$ \\
\hline $15: 57: 30: 27$ & $\begin{array}{l}\text { Good image of complete } \\
\text { mass of solid H2 }\end{array}$ & \multirow[t]{2}{*}{$16: 34: 50: 17$} & \multirow{2}{*}{$\begin{array}{l}\mathrm{H} 2 \text { agglomerate hits Visual } \\
\text { rake... }\end{array}$} \\
\hline \multirow[t]{2}{*}{$15: 59: 21: 15$} & \multirow{2}{*}{$\begin{array}{l}\text { Many good images of solid } \\
\text { h2 floating ( } 2 \text { pieces) }\end{array}$} & & \\
\hline & & \multirow{2}{*}{ 16:34:53:01 } & \multirow{2}{*}{$\begin{array}{l}\text { Boiling at temperature rake } \\
\text { small waves of clouds } \\
\text { appear... at bottom of FOV }\end{array}$} \\
\hline $16: 02: 54: 23$ & $\begin{array}{l}\text { Tiny particle seen.. } \\
\text { Analyze! }\end{array}$ & & \\
\hline $16: 03: 31: 04$ & Small doughnut seen & \multirow[t]{2}{*}{$16: 36: 27: 08$} & \multirow{2}{*}{$\begin{array}{l}\text { Small H2 mass breaks } \\
\text { away from Temperature } \\
\text { rake }\end{array}$} \\
\hline 16:04:53:07 & Better doughnut image & & \\
\hline $16: 05: 16: 08$ & $\begin{array}{l}\text { Many tiny particles are } \\
\text { evident... }\end{array}$ & $16: 36: 30: 08$ & $\begin{array}{l}\text { Small } \mathrm{H} 2 \text { mass attaches to } \\
\text { larger } \mathrm{H} 2 \text { mass }\end{array}$ \\
\hline 16:06:23:09 & $\begin{array}{l}\text { Straight "BEAMS" of solid } \\
\text { H2 evident ... VERY } \\
\text { DIFFERENT!! }\end{array}$ & $16: 37: 31: 18$ & End of tape \\
\hline
\end{tabular}


Tape 3

\begin{tabular}{|c|c|}
\hline $\begin{array}{l}\text { Event timing } \\
\text { (hh:mm:ss:ff) }\end{array}$ & Observations \\
\hline $16: 37: 54: 10$ & Begin tape 3 \\
\hline $16: 40: 37: 02$ & $\begin{array}{l}\mathrm{H} 2 \text { agglomerate is very } \\
\text { stable, attached to visual } \\
\text { rake. }\end{array}$ \\
\hline $16: 41: 42: 00$ & $\begin{array}{l}\text { Boiling at the temperature } \\
\text { rake }\end{array}$ \\
\hline 16:51:54:18 & $\begin{array}{l}\text { Begin lower pressure, } \\
\text { blasting particles.... }\end{array}$ \\
\hline $16: 51: 58: 27$ & $\underline{\text { GOOD FOV Edges }}$ \\
\hline 16:51:58:28 & $\underline{\text { GOOD FOV EDGE }}$ \\
\hline 16:52:03:18 & $\underline{\text { GOOD FOV EDGE }}$ \\
\hline $16: 53: 13: 05$ & $\begin{array}{l}\text { Clouds forming at tank is } \\
\text { evacuated at end of run.... }\end{array}$ \\
\hline $16: 53: 36: 00$ & $\begin{array}{l}\text { Waves of gas mesmerized } \\
\text { the viewer... () }\end{array}$ \\
\hline $16: 55: 28: 07$ & $\begin{array}{l}\text { Hundreds of tiny particles are } \\
\text { seen over the next few } \\
\text { minutes, dead center of FOV. } \\
\text { It is not clear if they are new } \\
\text { particles reforming form } \\
\text { agitated } \mathrm{H} 2 \text { mass, or H2 } \\
\text { frozen on wall that is coming } \\
\text { off the wall }\end{array}$ \\
\hline $16: 57: 56: 21$ & $\begin{array}{l}\text { Tiny particles continue to } \\
\text { appear....... }\end{array}$ \\
\hline 16:58:55:06 & $\begin{array}{l}\mathrm{H} 2 \text { agglomerate } \\
\text { reforms/regroups.... }\end{array}$ \\
\hline 16:59:01:10 & $\begin{array}{l}\text { Many tiny particles still } \\
\text { visible... }\end{array}$ \\
\hline 17:00:48:21 & $\begin{array}{l}\text { Image to determine } \\
\text { area/mass difference from } \\
\text { 16:41:42:00 }\end{array}$ \\
\hline 17:00:58:21 & "Clearer" image of H2 Area \\
\hline $17: 02: 57: 12$ & Very few tiny particles.... \\
\hline $17: 04: 21: 25$ & $\begin{array}{l}\text { Agitation clearly shows } \\
\text { clumps of h2 (aged) }\end{array}$ \\
\hline 17:07:53:21 & Clumps.... \\
\hline 17:17:02:23 & Clumps and more clumps \\
\hline $17: 34: 27: 22$ & $\begin{array}{l}\text { Clumps appear more } \\
\text { rounded, uniform..... }\end{array}$ \\
\hline 17:36:48:08 & $\begin{array}{l}\text { Large particle appears clear } \\
\text { or very clear }\end{array}$ \\
\hline 17:39:01:26 & End of tape \\
\hline
\end{tabular}

Tape 4

\begin{tabular}{|c|c|}
\hline $\begin{array}{l}\text { Event timing } \\
\text { (hh:mm:ss:ff) }\end{array}$ & Observations \\
\hline 17:39:30:17 & Beginning of tape \\
\hline $17: 40: 17: 23$ & $\begin{array}{l}\text { Particles Agitated as } \\
\text { Gas Departs Dewar }\end{array}$ \\
\hline 17:46:28:04 & $\begin{array}{l}\text { View becomes more } \\
\text { cloudy }\end{array}$ \\
\hline $17: 47: 24: 17$ & $\begin{array}{l}\text { See reflections of } \\
\text { particles on wall of } \\
\text { dewar. }\end{array}$ \\
\hline 17:50:33:01 & $\begin{array}{l}\text { See particle reflections } \\
\text { on dewar wall }\end{array}$ \\
\hline 17:51:47:29 & $\begin{array}{l}\text { Reflected images seem } \\
\text { enlarged, and distorted }\end{array}$ \\
\hline 17:54:10:28 & $\begin{array}{l}\text { Helium level in dish of } \\
\text { dewar, only }\end{array}$ \\
\hline 17:54:15:04 & $\begin{array}{l}\text { Particle reflections } \\
\text { look like Georgia } \\
\text { O'Keefe cloud } \\
\text { painting }(-)\end{array}$ \\
\hline 17:55:42:17 & $\begin{array}{l}\text { Small, tiny particles } \\
\text { Seem to reappear in } \\
\text { dewar dish, may be } \\
\text { boiling }\end{array}$ \\
\hline 17:58:12:03 & $\begin{array}{l}\text { Many tiny sites for } \\
\text { boiling at top of FOV }\end{array}$ \\
\hline 18:00:35:12 & $\begin{array}{l}\text { Beached } \mathrm{H} 2 \text { particle } \\
\text { nearly evaporated }\end{array}$ \\
\hline 18:02:29:29 & $\begin{array}{l}\text { Helium level receding } \\
\text { quickly }\end{array}$ \\
\hline 18:02:59:02 & $\begin{array}{l}\text { Last } \mathrm{H} 2 \text { particle is } \\
\text { vaporized / vaporizing }\end{array}$ \\
\hline 18:03:07:29 & All H2 is gone. \\
\hline 18:04:02:17 & $\begin{array}{l}\text { All helium is } \\
\text { vaporized }\end{array}$ \\
\hline 18:11:26:24 & End of tape \\
\hline
\end{tabular}



Appendix B

Solid hydrogen images from testing: February 27, 2001
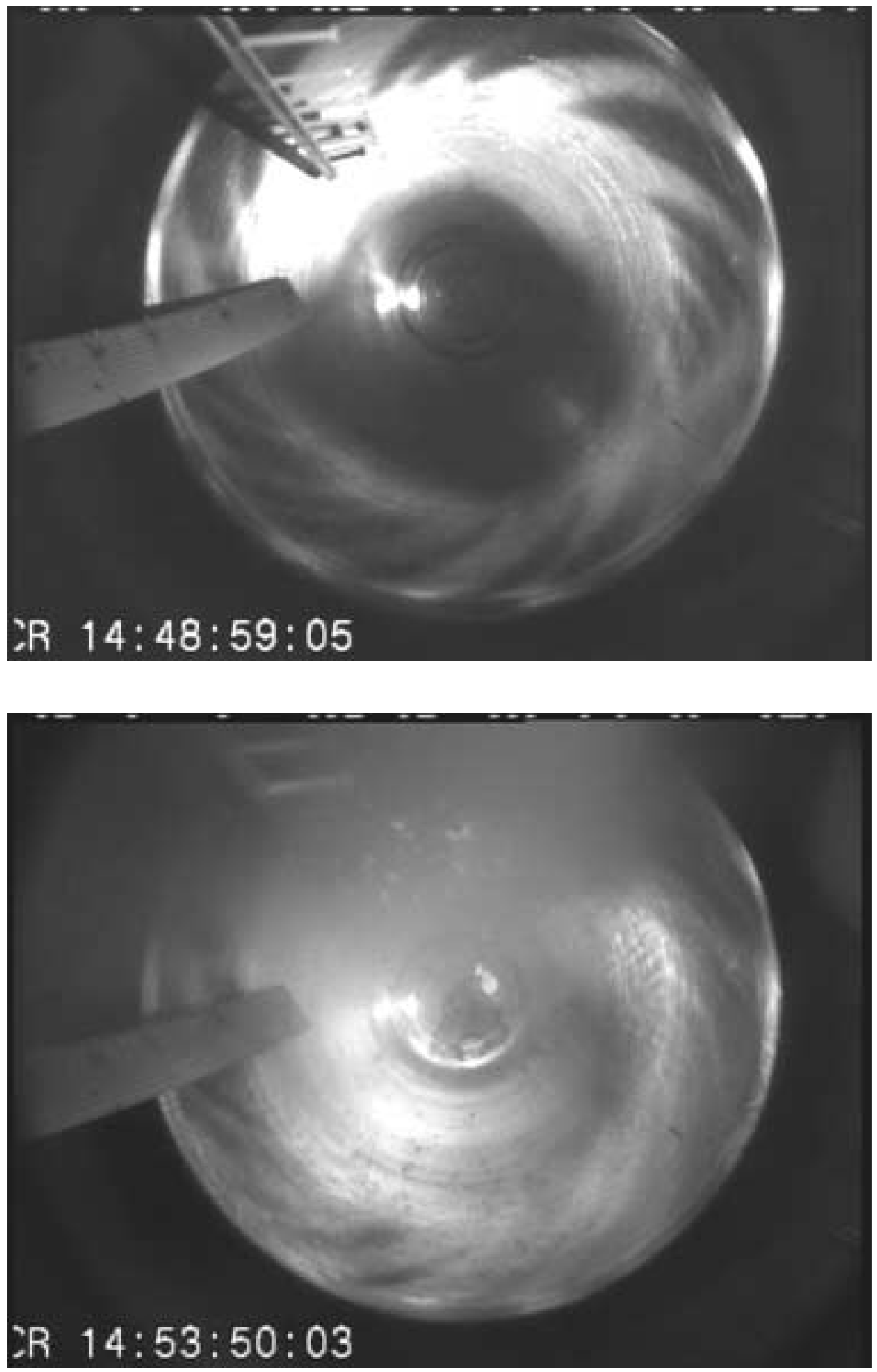

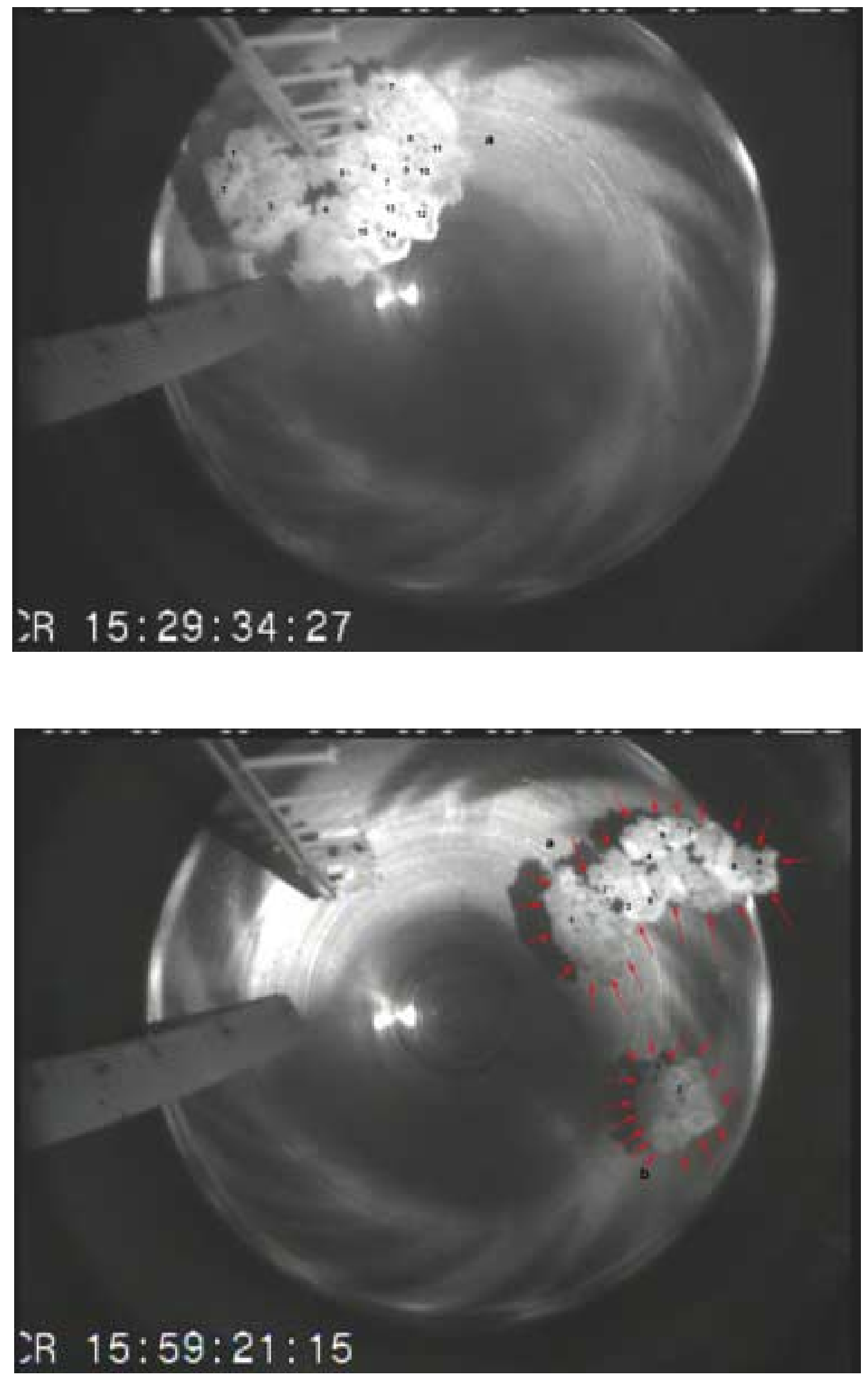

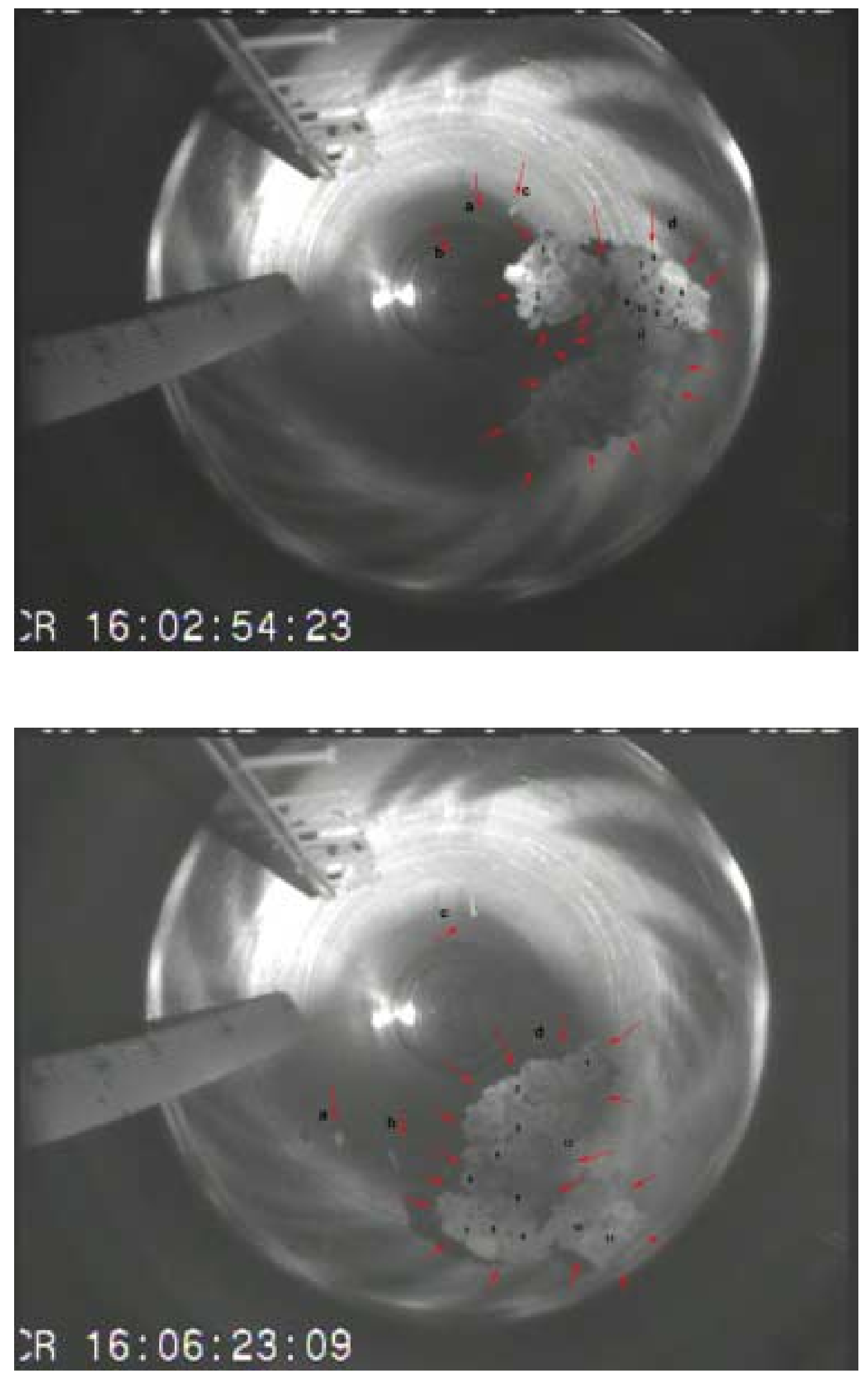

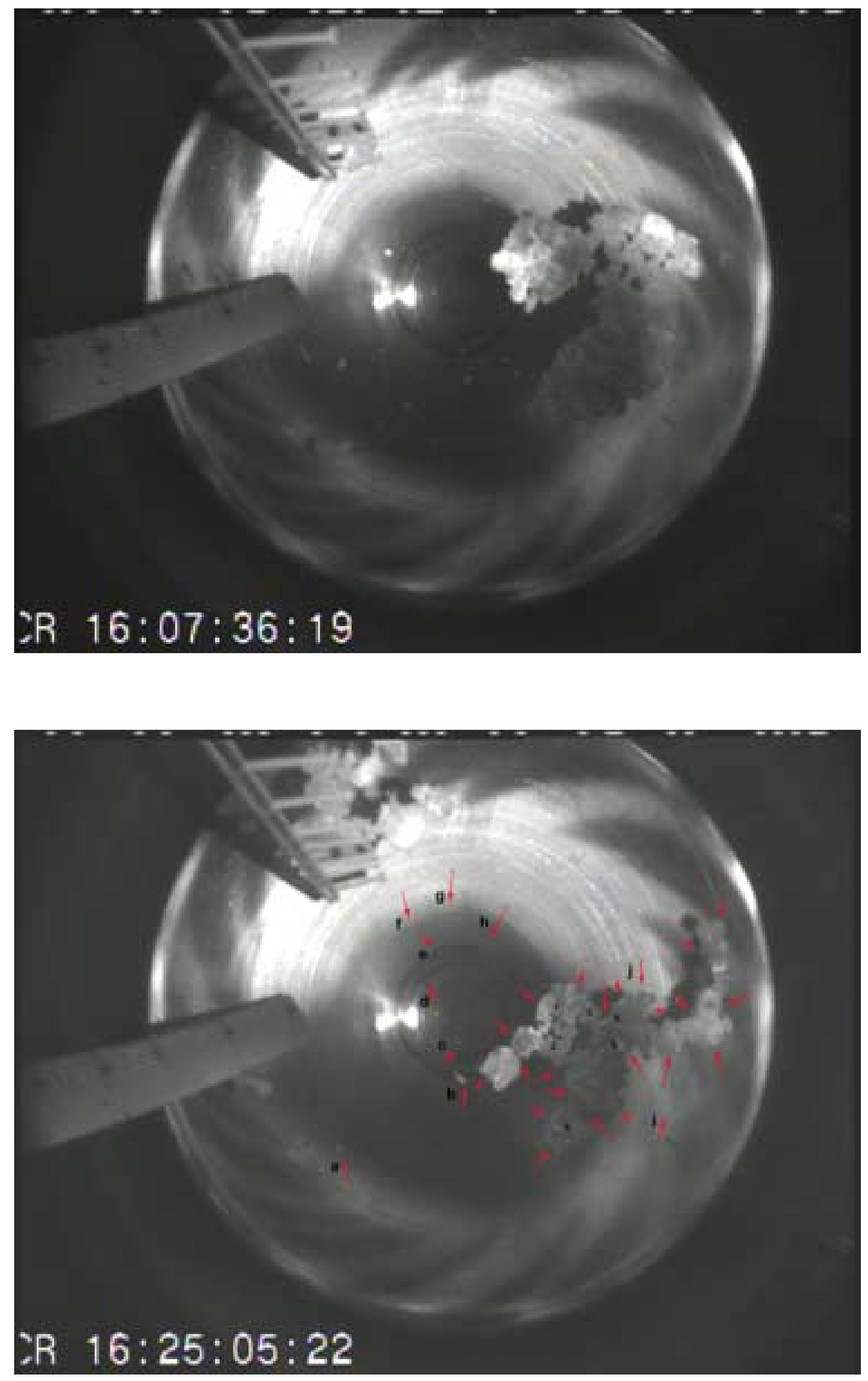


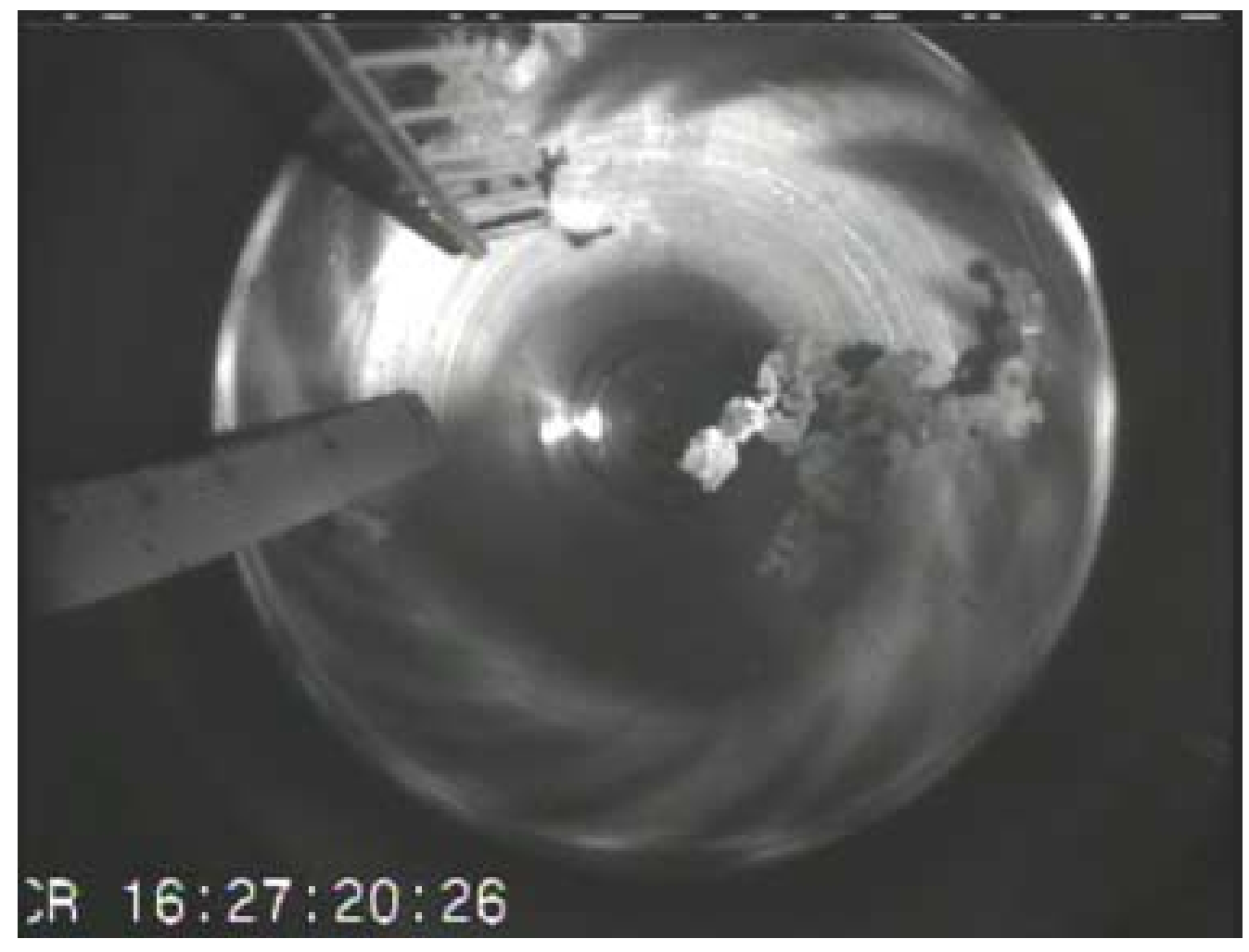




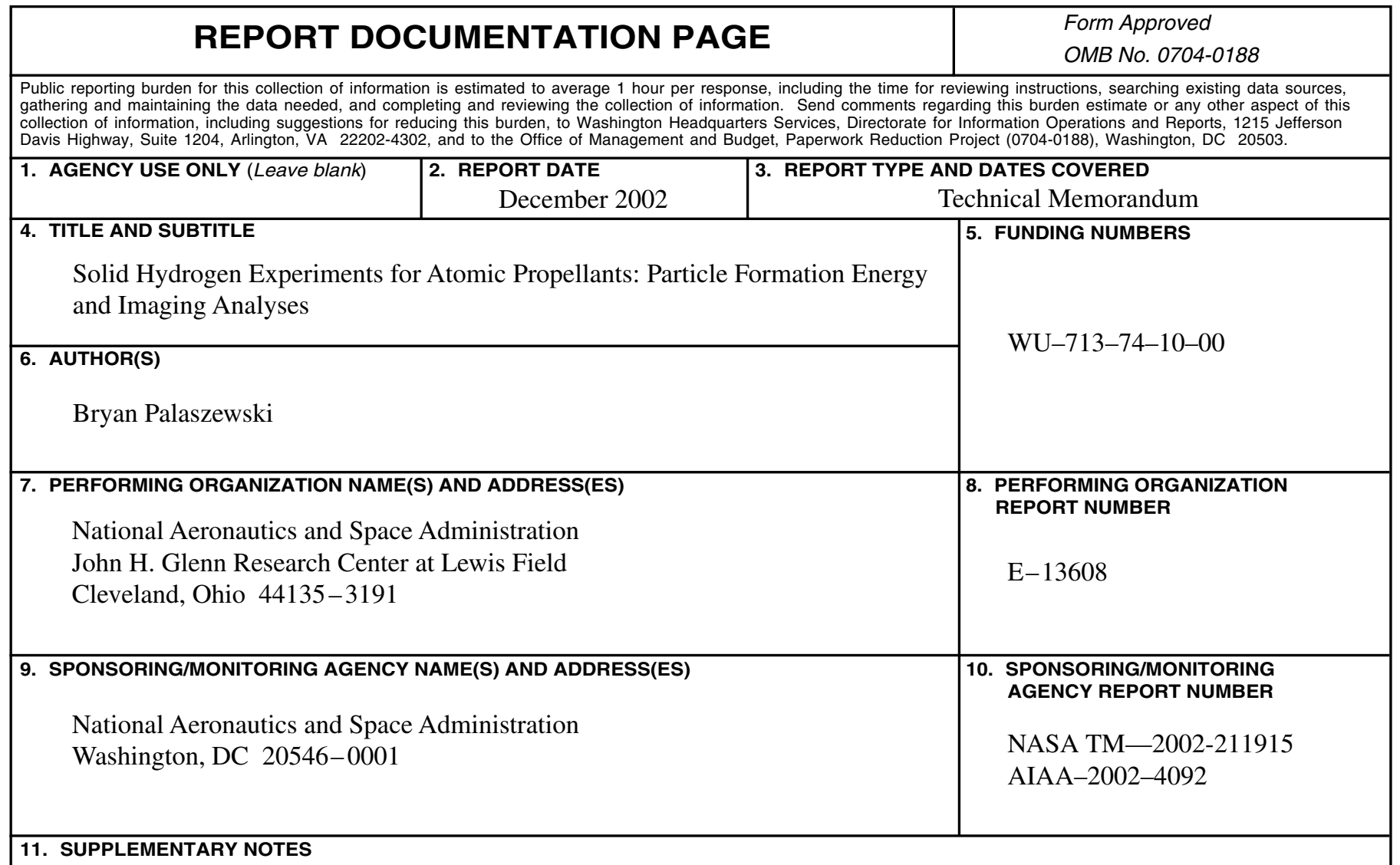

Prepared for the 38th Joint Propulsion Conference and Exhibit cosponsored by the AIAA, ASME, SAE, and ASEE, Indianapolis, Indiana, July 7-10, 2002. Responsible person, Bryan Palaszewski, organization code 5830, $216-977-7493$.

12a. DISTRIBUTION/AVAILABILITY STATEMENT

12b. DISTRIBUTION CODE

Unclassified - Unlimited

Subject Categories: 15, 20, and 28

Distribution: Nonstandard

Available electronically at http://gltrs.grc.nasa.gov

This publication is available from the NASA Center for AeroSpace Information, 301-621-0390.

13. ABSTRACT (Maximum 200 words)

This paper presents particle formation energy balances and detailed analyses of the images from experiments that were conducted on the formation of solid hydrogen particles in liquid helium during the Phase II testing in 2001. Solid particles of hydrogen were frozen in liquid helium and observed with a video camera. The solid hydrogen particle sizes and the total mass of hydrogen particles were estimated. The particle formation efficiency is also estimated. Particle sizes from the Phase I testing in 1999 and the Phase II testing in 2001 were similar. Though the 2001 testing created similar particles sizes, many new particle formation phenomena were observed. These experiment image analyses are one of the first steps toward visually characterizing these particles and it allows designers to understand what issues must be addressed in atomic propellant feed system designs for future aerospace vehicles. 14. SUBJECT TERMS
Cryogenics; Gelled propellants; Solid hydrogen; Helium; Rocket propulsion; High energy
density fuels

\begin{tabular}{|c|c|}
$\begin{array}{c}\text { 18. SECURITY CLASSIFICATION } \\
\text { OF THIS PAGE } \\
\text { Unclassified }\end{array}$ & $\begin{array}{c}\text { 19. SECURITY CLASSIFICATION } \\
\text { OF ABSTRACT } \\
\text { Unclassified }\end{array}$ \\
\hline
\end{tabular}

Standard Form 298 (Rev. 2-89)

Prescribed by ANSI Std. Z39-18 298-102 